\title{
Blue mussels Mytilus edulis do not interfere with eelgrass Zostera marina but fertilize shoot growth through biodeposition
}

\author{
Thorsten B. H. Reusch ${ }^{1}$, Anthony R. O. Chapman ${ }^{1,2}$, Joachim P. Gröger ${ }^{1}$ \\ ${ }^{1}$ Institut für Meereskunde, Düsternbrooker Weg 20, D-24105 Kiel, Germany \\ ${ }^{2}$ Dalhousie University, Department of Biology, Halifax, Nova Scotia, Canada B3H 4J1
}

\begin{abstract}
Blue mussels Mytilus edulis L. and eelgrass Zostera marina L. commonly co-occur in mixed stands at sheltered sites of the Western Baltic. The effects of mussels on density, vegetative propagation and growth of eelgrass were tested experimentally. Mussels were either added to $Z$. marina patches or removed from existing Zostera/Mytilus associations. We found no effect of these experimental manipulations on the shoot density of $Z$. marina from April to October Likewise, observations on a series of permanent plots over 1 growth period showed that adjacent mussel patches did not impede the vegetative propagation of eelgrass patches. Instead of damaging eelgrass by interference competition, mussels enhance eelgrass growth. At the end of August, plants in the $M$. edulis addition treatment had a $36 \%$ higher leaf area than the controls, whereas mussel removal led to an area decrease of $16 \%$ compared to the controls. Since, at the same time, the sediment porewater concentrations of ammonum and phosphate doubled in presence of $M$. edulis, we infer that $Z$. marina is nutrient-limited in the sandy, organically poor sediments of the shallow subtidal zone. $M$. edulis facilitates $Z$. marina by the biodeposition of organic material via faeces and pseudofaeces. A correlation between porewater ammonium concentration and plant size supports the contention that nitrogen is growth limiting. In contrast, no relationship was found between porewater phosphate concentration and plant size
\end{abstract}

KEY WORDS: Zostera. Mytilus Baltic Sea - Interference competition . Facilitation Nitrogen availability Biological interactions

\section{INTRODUCTION}

The co-occurence of blue mussels Mytilus edulis L. and eelgrass Zostera marina L. is a widespread phenomenon at sheltered sites of the shallow subtidal of Kiel Bight [e.g. Kiel Fjord; Schwenke (1969), authors' pers. obs.]. Besides pure Z. marina meadows and pure $M$. edulis beds, there are mixed stands (hereafter called Zostera/Mytilus associations). These combinations form a mosaic of patches, which are interspersed with sand (Fig. 1a).

There is anecdotal evidence for deleterious effects which Mytilus edulis may have on Zostera spp. In intertidal seagrass meadows of the Wadden Sea (North Sea), a rapid succession from meadows of $Z$. marina and Z. nana to mussel beds is frequently observed (Ruth
1991, pers, comm.). In Kiel Bight, Gründel (1980) observed the rapid conversion of an eelgrass meadow to a mussel bank within 1 yr following heavy settlement of juvenile mussels. At the experimental site of the present study in Friedrichsort, Kiel Fjord, Kobarg (1993) transplanted Zostera/Mytilus patches to greater water depth to study the light limitation of $Z$. marina. After 3 mo in deep water, $Z$. marina was destroyed by $M$. edulis and Kobarg (1993) attributed this to a mechanical damage of the shoots by the growing and extending mussel individuals. Observations made at the study sites revealed that in unmanipulated patches, lateral growth extensions of the dense mussel understory frequently bent Z. marina shoots aside (Fig. 1 b).

On rocky shores, mussels are often the top space competitors which restrict macroalgal distribution (e.g. 

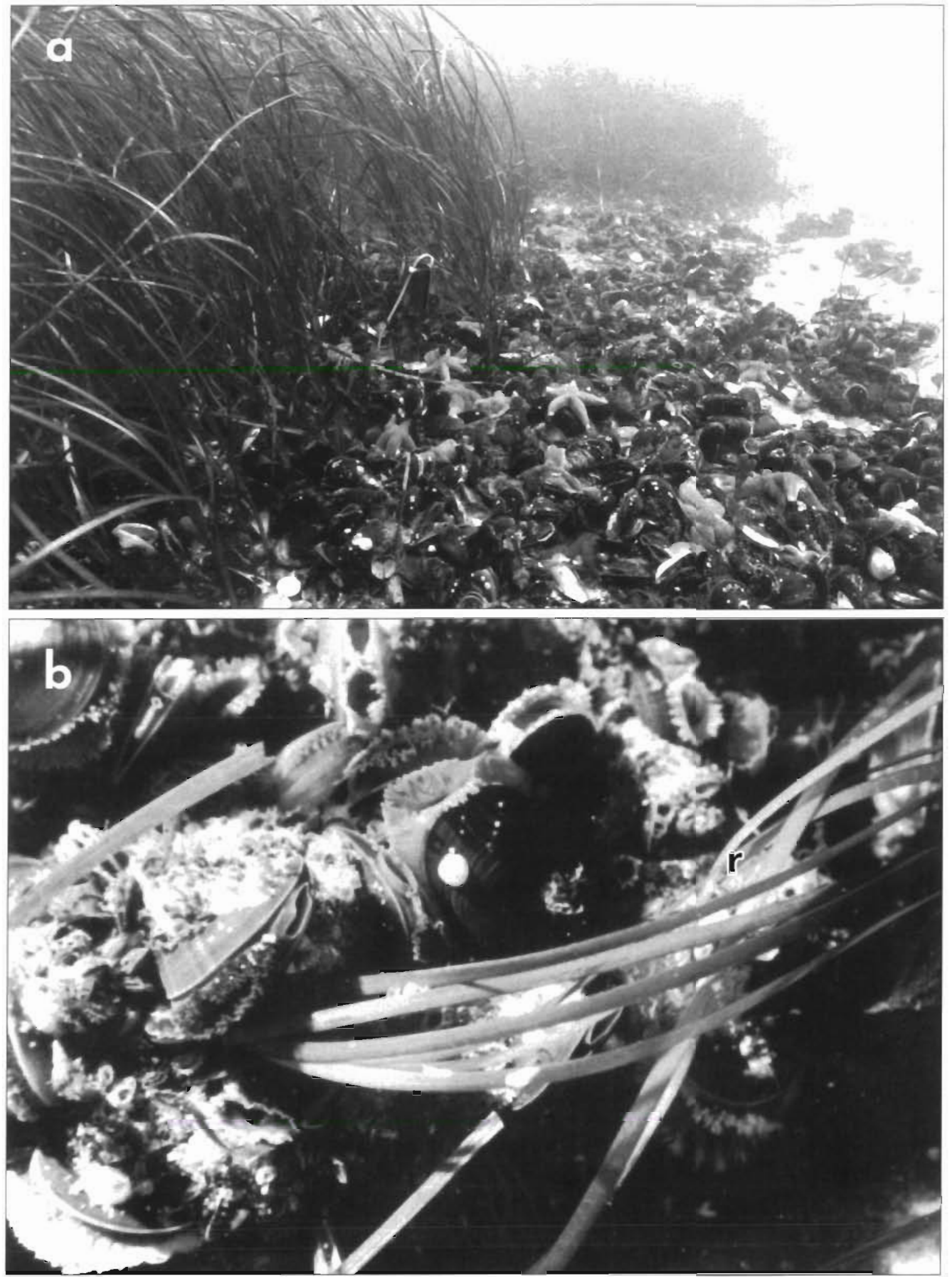

Fig. 1 Zostera marina, Mytilus edulis. (a) An eelgrass/blue mussel patch with an adjacent strip of pure mussels at MOE (Moltenort, Kiel Fjord, Germany) in $1.8 \mathrm{~m}$ depth on September 6. 1993. Note the margin of the mussel patch extending onto the bare sand and the marking stake in the center of the picture. (b) Detail of a dense $M$. edulis understory bending a $Z$. marina shoot asıde (r). Photograph was taken in March 1993 at the experimental site FO (Friedrichsort, Kiel. Fjord) in $2 \mathrm{~m}$ depth 
Dayton 1971, Paine 1971, Menge 1976). In contrast, for soft-bottom communities competition for space has seldom been shown to structure the community (Woodin 1976, Peterson 1977, Brenchley 1982) Spatial interference is thought to be rare because the 3 dimensional space on soft bottom provides spatial refuges in excess. Moreover, on soft bottom no fixed attachment points exist from which sessile organisms may push or squeeze competitively inferior organisms off the substratum (Peterson 1979), except in very rare events where infaunal molluscs settle in such a high density that they push conspecifics out of the sediment (Dijkema et al. 1987).

However, mytilid mussels are known to compete intraspecifically for space if occurring in epibenthic beds or clumps of conspecifics. The forces individuals may exert on their neighbours suppress growth (Fréchette \& Lafaivre 1990) and may even lead to shell deformation (Harger 1972, Bertness \& Grossholz 1985).

One major goal of this study is to test whether there is any deleterious effect of Mytilus edulis on Zostera marina. We hypothesize that $Z$. marina shoot density declines over time if interference competition occurs. In an experimental manipulation of $M$. edulis coverage, we assess the effects of $M$. edulis on $Z$. marina densities. With a series of permanent plots over adjacent patches, we test if the vegetative propagation of $Z$. marina is inhibited by the presence of an adjacent mussel bank

Besides having a potential competitive role, mussels are reported to fertilize co-occurring algae (Kautsky \& Wallentinus 1980). Therefore, the second objective of this study is to test whether Mytilus edulis enhances Zostera marina growth by fertilization. In the case of marine angiosperms, not only water column excretion but also nutrient enrichment of the sediment by the mussels may be responsible for potential growth effects (Bertness 1984), since seagrasses obtain the greatest fraction of their nutrient demands via roots from the sediment (Barko et al. 1991). The biodeposits of pseudofaeces and faeces of Baltic blue mussels were shown to be high in nitrogen content despite having passed through the mussel intestine (Kautsky \& Evans 1987). Therefore, the effects of experimental changes of $M$. edulis densities on the sediment nutrient content will be assessed as well.

\section{MATERIAL, AND METHODS}

Study period and sites. Observations were carried out from June 1992 until October 1993 using SCUBA diving. The experiments were run during 1 Zostera marina growth period from April until October 1993 at Friedrichsort (hereafter FO), Kiel Fjord, Western Baltic, in a military restricted area. Additional observational data were obtained at Möltenort (hereafter MOE) which is situated opposite to FO on the eastern side of Kiel Fjord (Fig. 2). Salinitics ranged from 13 to $20 \%$ in the surface water and temperatures from 1.7 to $19^{\circ} \mathrm{C}$ during the study period. Although no lunar tides occur in the Baltic Sea, irregular wind-driven sea level changes often have an amplitude of +50 to $-50 \mathrm{~cm}$ around mean water level (MWL) and a decline of - $1 \mathrm{~m}$ below MWL was attained during strong southwesterly gales several times in winter 1992-93. Therefore, the upper parts of the Zostera/Mytilus association, but not the permanent plots or experimental areas, were exposed to air.

Both sites are sheltered with a maximal wind fetch of $7 \mathrm{~km}$ and $6 \mathrm{~km}$ from southerly directions for FO and southwesterlies for MOE, respectively (Fig. 2). MOE may receive swells from severe northern storms against which FO is completely protected. The prevailing wind direction in this region of Europe is southwesterly, therefore both sites are regularly exposed to waves of 0.3 to $0.5 \mathrm{~m}$ height. The sediment of both sites consists of well sorted, medium grained silicate sand with 50 to $60 \%$ of the dry weight belonging to the

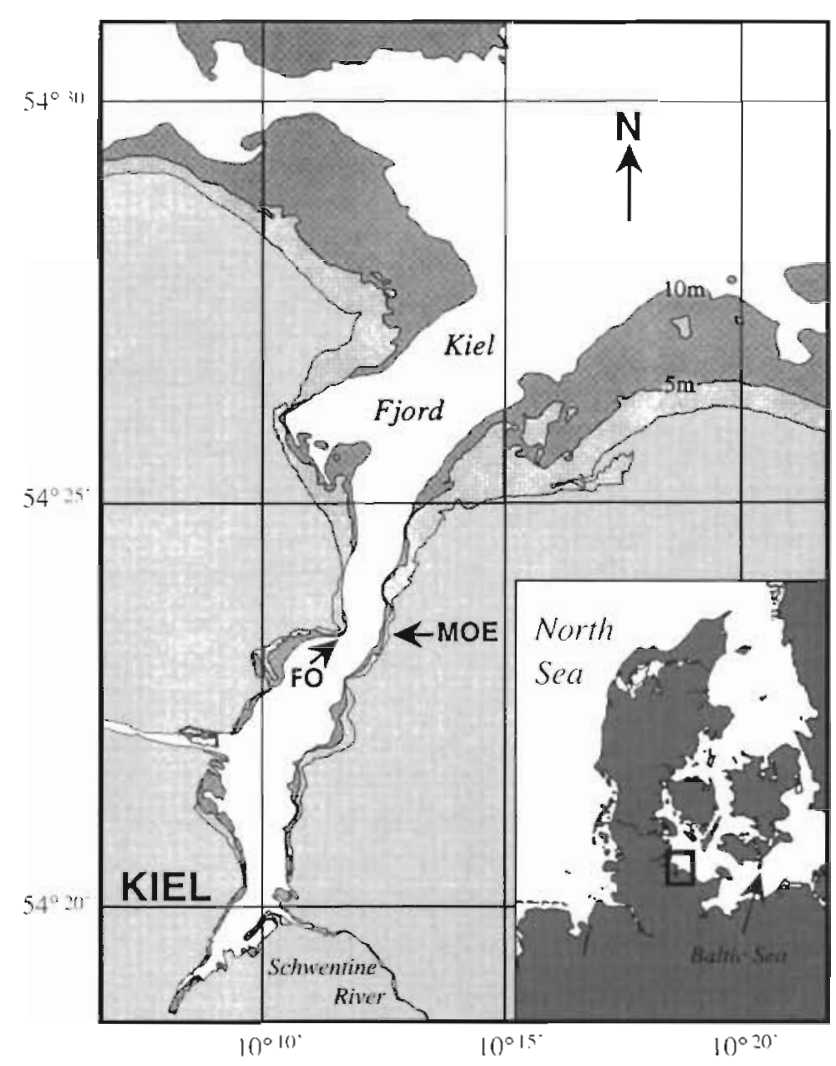

Fig. 2. Study sites located in Kiel Fjord, Western Baltic. All experiments were done in a military restricted area at Friedrichsort (FO), Germany. Additional observational data were obtained at Möltenort (MOE) 
250 to $500 \mu \mathrm{m}$ fraction. It is poor in organic content $[0.42 \pm 0.06 \%$ SD loss of ignition (LOI) on bare sand, $\mathrm{n}=5]$.

The distribution depth of the Zostera/Mytilus association is between 1.2 and $2.5 \mathrm{~m}$ in FO and 1.0 and $2.2 \mathrm{~m}$ in MOE. Further down to a depth of approximately $4 \mathrm{~m}$ pure patches of $Z$. marina occur. The shape of the patches is irregular, ranging from ellipses to narrow, elongated structures which are mostly orientated perpendicular to the shoreline. Their extension on the longest axis of both pure Z. marina and Zosteral Mytilus patches ranges from 0.5 to approximately $5 \mathrm{~m}$, with a high percentage of patches measuring between 1 and $3 \mathrm{~m}$. Those sizes were chosen for the experimental manipulations.

On the gentle slopes at both sites, the depth band with co-occurring Zostera marina and Mytilus edulis is approximately $30 \mathrm{~m}$ wide. The coverage of the substratum with eelgrass, pure mussel banks and the Zostera/Mytilus association is shown in Fig. 3. In March 1993, 39\% of the $Z$. marina meadows at FO and $71 \%$ at $\mathrm{MOE}$ possessed an understory of mussels. Typically, they form an almost continuous, epibenthic layer underneath the $Z$. marina canopy, and they are not hummocked (Fig. 1a, b). The byssus threads of the mussels are rarely attached to $Z$. marina shoots or rhizomes but usually to other mussels. This allowed the removal of $M$. edulis without damaging $Z$. marina plants (see below).

Field observations. Determination of plant parameters of Zostera marina: At both sites, the plant morphology was determined between August 25 and September 2, 1993, comparing plots with and without Mytilus edulis from the same depth range from 1.8 to $2 \mathrm{~m}$. In each of the 7 plots of $50 \times 50 \mathrm{~cm}^{2}, 6$ plants were chosen haphazardly by blindly pointing into the plot

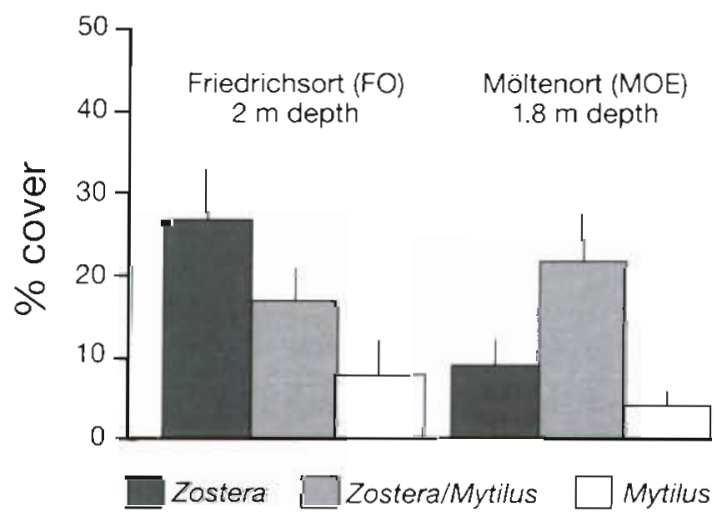

Fig. 3. Zostera marina, Mytilus edulis. Substratum coverage $+1 \mathrm{SE}$ at Friedrichsort (FO) and Möltenort (MOE) on March 20 and 25,1993 , respectively. 16 quadrats of $1 \times 1 \mathrm{~m}^{2}$ were placed at random within a strip of $100 \mathrm{~m}$ length and $10 \mathrm{~m}$ width parallel to the shoreline with a ruler, thus total sample size was $n=42$. Only adult, fully grown plants were measured, whereas those which had recently developed from the rhizome were ignored.

The length of the largest photosynthetically active leaf was measured to the nearest $\mathrm{cm}$ and its width to the nearest $0.5 \mathrm{~mm}$. The leaf area was calculated by multiplication assuming a rectangular shape. The width of the leaves was constant over the whole length (pers. obs.). In concordance with studies on Danish Baltic seagrass meadows (Sand-Jensen 1975), we found that the largest photosynthetically active leaf of Zostera marina was in most cases the 4 th youngest.

All shoot densities were determined in areas of $50 \times$ $50 \mathrm{~cm}^{2}$. Each leaf bundle, including those recently formed, counted as 1 shoot. To make counts as accurate as possible, the plot area was subdivided with 2 stakes inta strips of $10 \mathrm{~cm}$ width. To determine the accuracy of the method, counts of shoot density on 3 plots were repeated 3 times in April. The error was smaller than $5 \%$. All counts were made by the same observer.

To determine the ratio of aboveground to belowground biomass, and the length of the roots in pure Zostera marina compared to the Zostera/Mytilus association, 5 destructive core samples $\left(250 \mathrm{~cm}^{2}, 15 \mathrm{~cm}\right.$ depth) were taken at MOE on September 1, 1993, on each substratum type. The samples were divided into leaves (aboveground biomass) and rhizomes plus roots (belowground biomass), rinsed with fresh water and weighed after drying at $80^{\circ} \mathrm{C}$ for $24 \mathrm{~h}$. Ten roots in each core were chosen at random and measured from attachment base at the rhizome to the tip to the nearest $\mathrm{mm}$.

Sediment analysis: Sediment samples were taken in $50 \mathrm{ml}$ plastic vials $(5 \mathrm{~cm}$ i.d.) which were inserted $5 \mathrm{~cm}$ into the sediment. On August 2, 1993, 3 samples were taken in each of the 5 control plots of a Mytilus edulis addition/removal experiment at FO. The organic content of the sediment was determined as LOI by drying the sample at $100^{\circ} \mathrm{C}$ and determining the weight loss after heating at $500^{\circ} \mathrm{C}$ for $12 \mathrm{~h}$ in a muffle furnace.

Porewater was sampled in triplicate at FO on August 26, 1993, in all 20 experimental plots and at MOE on September 2, 1993, in 5 Zostera marina plots each in the presence and absence of Mytilus edulis. The samples were obtained in situ with $10 \mathrm{ml}$ plastic syringes. A plastic tip was perforated several times and a $20 \mu \mathrm{m}$ mesh gauze wrapped around it. At 3 randomly chosen points, they were inserted $5 \mathrm{~cm}$ into the substratum using a new syringe for each subsample. By gently sucking over a period of approximately $30 \mathrm{~s}$, $10 \mathrm{ml}$ of porewater was sampled from the 4 to $6 \mathrm{~cm}$ depth horizon. The chosen depth lies within the densest root/rhizome development (pers. obs.). Samples were deep frozen on board the dive boat. Since 
the concentration of ammonium in the porewater is generally $>20 \mu \mathrm{M}$, changes in concentration due to freezing were considered non-significant. In the laboratory, the samples were diluted 1:5 with distilled water and analysed for nitrate/nitrite, dissolved ammonium and soluble reactive phosphate (SRP) after the methods of Grasshoff (1976), Koroleff (1976a), and Koroleff (1976b) modified for a smaller sample volume. In concentrations $>150 \mu \mathrm{M}, \mathrm{H}_{2} \mathrm{~S}$ may interfere with determination of ammonium and lead to false positive results of 7 to $14 \%$ (Koroleff 1976a). However, we assumed the $\mathrm{H}_{2} \mathrm{~S}$ concentrations in the porewater to be markedly below this value since core samples never smelled sulfidic. The photometric measurements were corrected for turbidity.

Shoot density, leaf length and width, and nutrient concentrations in the porewater were compared between sites (FO and MOE) and between substrata with a $2 \times 2$ nested ANOVA with site and presence/ absence of Mytilus edulis as factors and plot nested in both factors. The response variables leaf length, width and area were log-transformed, nutrient concentrations were cubic-root-transformed and shoot densities square-root-transformed to remove heterogeneity of variances. Cochran's test was applied to test the success of the transformation. The 3 leaf parameters measured were considered as parts of 1 mensurative experiment on general differences in leaf morphology. Therefore, to minimise the chance of committing a type I error, the significance levels were Bonferroniadjusted by dividing $\alpha$ (probability of making a type I error) by the numbers of comparisons, i.e. 3. These and all subsequent statistical analyses were performed with SuperANOVA (Abacus Concepts), SYSTAT version 5.1. (Systat, Inc.), or Kaleidagraph (Abelbeck software), using a Macintosh II computer.

Regression of sediment nutrients on Zostera marina leaf length: During late August 1993, 20 triplicate porewater determinations were performed at FO and 10 determinations at MOE, half of each on Zostera marina plots with and without a mussel understory. Simultaneously we measured length of the largest photosynthetically active leaf of $Z$. marina in the same plots between August 26 and September 3, 1993. We estimated relative differences in $Z$. marina growth between treatments from the lengths of the largest intact leaves (Hamburg \& Homann 1986). To do this, we assumed that the rate of new leaf formation (the plastochrone interval) and hence the age of the leaves until they stop growth is similar among the treatments. If there is acceleration with nutrient enrichment, increases in leaf growth rate would be underestimated by this method.

In concordance with work done by Sand-Jensen (1975) we observed that leaves stop growing when they become the 3 rd youngest leaf of one shoot.
Since the relation between eelgrass growth and nutrients is not linear, but follows a saturation-type function (Dennison et al. 1987, Williams \& Ruckelshaus 1993), a Monod curve was calculated between the corresponding sample means of sediment porewater $(\mathrm{n}=3)$ as the independent variable and the leaf length $(n=6)$ as the dependent variable using a least-square approximation method. For ammonium as dependent variable only, a Woolf linear transformation (leaf length/ ammonium concentration vs ammonium concentration) was used to test the significance of the regression by an ANOVA.

Observations on patch boundaries: Permanent plots were followed through time to gain information on whether (1) the presence of adjacent mussel beds impedes vegetative propagation of eelgrass and (2) fertilization by co-occuring mussels accelerates the rate of vegetative propagation compared to pure eelgrass stands. No Zostera marina seedlings were found throughout the study period in the water depth investigated. Thus, extension of $Z$. marina patches occurred only through vegetative propagation.

The positions of borders of approximately $50 \mathrm{~cm}$ length were sampled photographically in quadrats of $50 \times 50 \mathrm{~cm}^{2}$. An accuracy of $1 \mathrm{~cm}$ was achieved using marking stakes at 2 diagonal edges. Ten plots on the following combinations of patch boundaries were chosen haphazardly within a strip of $80 \mathrm{~m}$ parallel to the shoreline in the 1.8 to $2 \mathrm{~m}$ depth: (1) pure Zostera marina vs sand; (2) pure $Z$. marina vs Mytilus edulis; (3) Zostera/Mytilus vs $M$ edulis; and (4) Zostera/ Mytilus vs sand. Border type 2 could not be sampled because a severe storm destroyed most of the pure mussel banks on October 10, 1993. The remaining permanent areas were carefully examined $3 \mathrm{~d}$ after the disturbance event to exclude every border which was apparently damaged by the storm, for we were interested only in border shifts due to growth processes. Due to the storm, the final sample size had to be reduced from a planned 10 to 8 independent pairs of adjacent patches.

The pasitions of borders were sampled on April 5 and on October 18, 1993. Non-destructive sampling using a camera with flash attached to a frame was feasible since Zostera marina canopy and shoot density were sufficiently low on the chosen sampling dates, that is before and after the growth period. The colour slides were then digitized using an S-VHS-Videocamera plugged into a NeXT workstation. Using the digitized image, in each replicate plot, patch boundaries were selected in the following way: to be included into a patch, no shoot could be more than $12 \mathrm{~cm}$ away from a conspecific. Spring and autumn boundary positions were drawn into a coordinate system. The border shifts were quantified by measuring the small- 
est distance between the spring and the autumn border at 5 randomly chosen points of the spring border within each plot. Image analysis software was developed in our department. In cases of doubt, the colour slide was investigated using a stereo-microscope.

Five distances were obtained for each of the 8 replicates of one border type, thus the total sample size was $n=40$ propagation distances for each border type. The distances were $(\log +1)$-transformed to remove heterogeneity of variances. A Cochran test for homoscedasticity was performed to confirm the success of the transformation. The 3 different border types were compared with a 1-way ANOVA nesting the 5 distances obtained for each replicate plot within the factor 'border type' to account for large variation within one border type.

Experiments. Changing Mytilus edulis densities: Two sub-experiments were carried out. In a Mytilus edulis addition experiment, mussels were transplanted into pure Zostera marina plots and thus artificial Zostera/Mytilus associations were produced. In a $M$. edulis removal experiment mussels were removed from existing associations (Fig. 4a). The chosen depth range was narrow ( 1.8 to $2 \mathrm{~m}$ ) and identical to the other observational sampling sites. The experimental layout was not completely randomized, because preliminary observations revealed a high variability in shoot density and plant size among patches in the same water depth. Therefore, each sub-experiment was performed as a randomized block design (Hurlbert 1984) (see Fig. 4b). Within a strip of $50 \mathrm{~m}$ length and $10 \mathrm{~m}$ width parallel to the shoreline, 5 blocks were selected haphazardly for each sub-experiment. The size and density of $Z$. marina was chosen to be as homogeneous as possible. The coverage of mussels in the Zostera/ Mytilus plots was always $100 \%$ before the experimental manipulation. Within each block, the positions of treatment and control plots were chosen at random The plats of $50 \times 50 \mathrm{~cm}^{2}$ were placed diagonal to each other without any intermediate space to minimize sediment and exposure variability within each block (Fig. 4a). Since both plots have contact only at a quadrat corner, we assume that interference between treatment and control is probably small.

All mussels were removed from Mytilus/Zostera patches. In 3 removal plots, the number of $Z$. marina shoots was counted before and after treatment to account for treatment effects. As greatest care was taken in removing the mussels without diving gloves, losses of shoots were minimized to between 2 and $7 \%$, and therefore considered as unimportant for the outcome of the experiment. The number of $Z$. marina shoots after experimental manipulation counted as the initial value for the experiment.

a

\section{Mytilus-removal experiment}

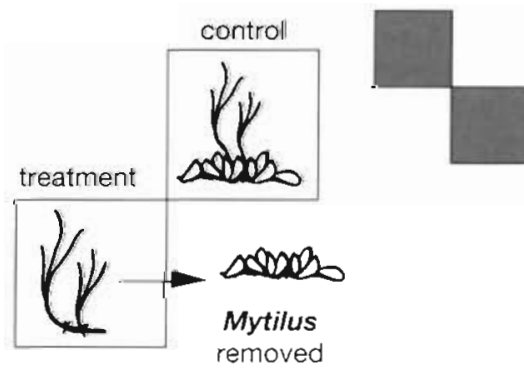

b

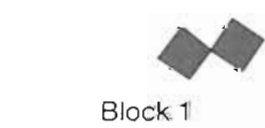

Block 1

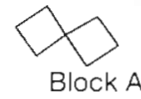

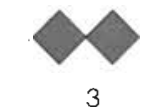

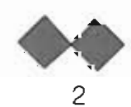

\section{Mytilus-addition experiment}

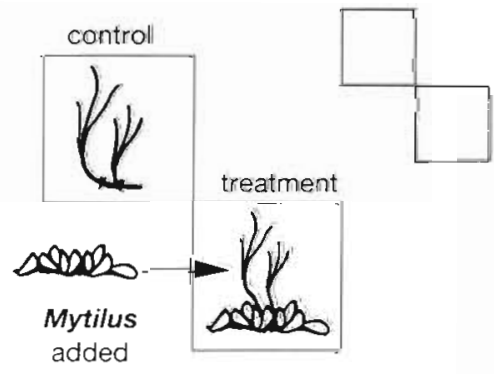

$B$<smiles></smiles>

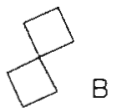

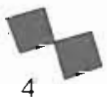

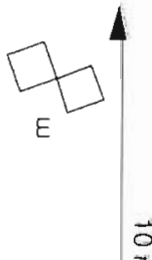

$\overrightarrow{0}$

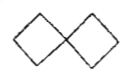

D
Fig. 4. (a) Experimental treatments and controls and (b) representation of the experimental block design of the Mytilus edulis addition and removal experiment. Blocks $A$ to $E$ and 1 to 5 belong to different subexperiments. The size of the quadrats is $50 \times 50 \mathrm{~cm}^{2}$ 
The removed mussels of the first sub-experiment were immediately transplanted into the pure Zostera marina plots which were chosen to receive the treatment of Mytilus edulis addition. For both experiments, the volume of mussels removed and subsequently added to another plot was about $4 \mathrm{dm}^{3}$. Before transplanting, the mussel clumps were broken into smaller aggregates because this (1) facilitated the homogenous dispersion on the bottom, (2) prevented the $Z$. marina shootlings from being bent to the ground by bigger clumps, and (3) provided a stimulus for byssus secretion and attachment to conspecifics (pers. obs.). During the first week only, wire fences of $10 \times 10 \mathrm{~mm}^{2}$ mesh size and $10 \mathrm{~cm}$ height surrounded plots which received mussels to prevent the unattached animals from being washed away from the treatment plots due to wave action. After that period, most mussels had attached to their neighbours and no difference between natural and artificially generated Mytilus/Zostera associations was apparent. The experiment lasted for $7.5 \mathrm{mo}$ from April 10 to October 27, 1993. In all plots, mussel cover remained at $>90 \%$ during the experimental period.

In both sub-experiments, response variables were (1) the number of Zostera marina shoots censused every 6 wk as described above, (2) length, width and area of the largest photosynthetically active leaf, determined as described above, on August 28, 1993, and (3) porewater nutrient concentrations sampled in triplicate in each plot on August 26, 1993.

Statistical analysis: Two different hypotheses were formulated on the effects of mussels on shoot density. The first is that the manipulation of Mytilus edulis cover led to differences in Zostera marina density after 6 mo of experimental duration, i.e. on the last sampling date (October 27). Therefore, October densities were analysed with 2 separate univariate analyses of covariance (hereafter ANCOVA), using the initial density as covariate.

The second hypothesis states that there is a difference in Zostera marina density as a result of experimental manipulation throughout the entire growth period (June to October). To test for this hypothesis, shoot densities were analysed with a multivariate analysis of variance (MANOVA), treating the 4 postmanipulative sampling dates (June 2, July 21, September 2, October 27) as 1 dependent vector (Farrell 1989; Howell 1992, p. 472). This multivariate analysis has the advantage of having a greater power of detecting a real difference. At the same time, it minimizes the risk of committing a type I error and eliminates the problem of non-independence among consecutive sampling dates (Johnson \& Field 1993). In fact, the 4 vectors of dependent variables were not independent but highly correlated among each other as can be expected in a repeated measure design. We tested this by comparing the covariance matrices of both treatments and both experiments against the identity matrix (which assumes no correlation) with a likelihood test (Fahrmeir \& Hamerle 1984, p. 74 ff.).

The MANOVA assumptions of multi-normality and multi-homoscedasticity were tested independently by 2 procedures. The 4 -dimensional normality was checked on the basis of a modified Choletzky decomposition, simultaneously testing kurtosis and skewness vectors of the dependent variables with a chi-squared distribution (Lütkepohl 1991). Multi-homoscedasticity and -normality were tested simultaneously using Hawkins' test (Hawkins 1981, proposed by Johnson \& Field 1993). In both analyses, the computed test statistic $W$ exceeded the critical value $\left(W_{\alpha=0.05}: 2.492 ;\right.$ Mytilus edulis addition $W_{1}=10.58, W_{2}=12.48 ; M$. edulis removal $\left.W_{1}=12.5, W_{2}=10.53\right)$. This indicated heteroscedasticity since the normality assumption was already fulfilled. However, Johnson \& Field (1993) propose a check for the differences in the medians of the tails of the F-distribution (i.e. the difference of the medians of $A_{1 j}$ s of each group; Hawkins 1981). If, in the case of a balanced design, the difference is smaller than 0.85 . Johnson \& Field assume that violation of the assumption of homoscedasticity is not harmful to the outcome of the analysis. The differences in our data are markedly smaller $(M$. edulis addition expt: $0.337 ; M$. edulis removal expt: 0.537 ). Therefore, we conclude that it is legitimate for us to perform a MANOVA.

For hypothesis testing, we chose the Pillai Tracestatistic and its $F$-approximation. It is recommended by Johnson \& Field (1993) as being the most robust against violations of multi-normality and multihomoscedasticity compared to other multivariate statistics (e.g. Hotelling's Trace, Wilk's lambda).

On the same data sets, we also performed MANCOVAs with initial shoot densities as covariates. In both analyses, the effect of the initial density (= covariate) was not significant. If this is the case, including the covariate into the analysis does not increase the power of the test but wastes degrees of freedom due to overparametrization (Bernstein 1987, p. 342). Hence, the outcomes of the MANCOVAs (which were not different from the MANOVAs considering the factor Mytilus edulis present/absent) are not shown and interpretation of the results was entirely based on the MANOVAs.

Additionally, the shoot densities of the 5 unmanipulated control plots of both sub-experiments were analysed for all 5 sampling dates (including the initial density on April 10) with a MANOVA, treating all sampling dates as 1 dependent vector

Response variable as well as covariate shoot densities were square-root-transformed to remove heterogeneity of variances. 
Effects of presence or absence of mussels on Zostera marina leaf parameters and sediment porewater were analysed with 2 sets of ANOVA models with blocking factor for each sub-experiment. The 3 leaf parameters measured were considered as parts of one mensurative experiment on general differences in leaf morphology. Therefore, to minimise the chance of committing a type I error, the significance levels were Bonferroni-adjusted by dividing $\alpha$ (probability of making a type I error) by the numbers of comparisons, i.e. 3. Leaf length, width and area were log-transformed and nutrient concentrations were cubic-roottransformed to remove heterogeneity of variances. Cochran's test was applied to test the success of the transformation.

\section{RESULTS}

\section{Field observations}

Shoot density. The shoot densities in August at FO and MOE were not significantly different in the presence or absence of Mytilus edulis (Fig. 5a, Table 1). The site had a significant effect on shoot density, but the interaction term Site $\times$ Mytilus absent/present was not significant, i.e. the effect of mussels on Zostera marina density is site independent.

Plant morphology. In contrast to density, plant morphology was dependent on the presence or absence of Mytilus edulis. At both sites, the length, width and area of the largest photosynthetically active leaf (in most cases the 4 th youngest leaf) were higher when Zostera marina grew with an understory of mussels. The effect of the site was also highly significant but not the interaction term Site $\times$ Mytilus absence/presence, i.e. the effect of $M$. edulis on $Z$. marina morphology is independent of site (Table 1, Fig. $5 b$ to d).

Destructive sampling of Zostera marina in MOE showed that the ratio of aboveground to belowground biomass was higher and the roots of $Z$. marina were significantly shorter if co-occurring with Mytilus edulis (Fig. 6e, f, Table 1).

Sediment parameters. Fig. 6 summarizes the differences of various sediment parameters between Zostera marina patches with and without Mytilus edulis. At FO, the organic content of the upper sediment horizon $(0$ to $5 \mathrm{~cm}$ ) is generally low (means $\pm 1 \mathrm{SE}: 1.02 \pm 0.12 \%$ LOI in pure $Z$. marina patches, $1.60 \pm 0.13 \%$ LOI in Zostera/Mytilus patches). The difference in LOI between $Z$. marina patches in presence or absence of $M$. edulis is significant ( 1 -way nested ANOVA, number of patches $n=7$, total number of samples $n=21, F_{(1,12)}$ $=8.324, \mathrm{p}=0.0137$ ).

At both sites, the porewater of the sediment horizon ( 3 to $6 \mathrm{~cm}$ ) in the Zostera/Mytilus association contains
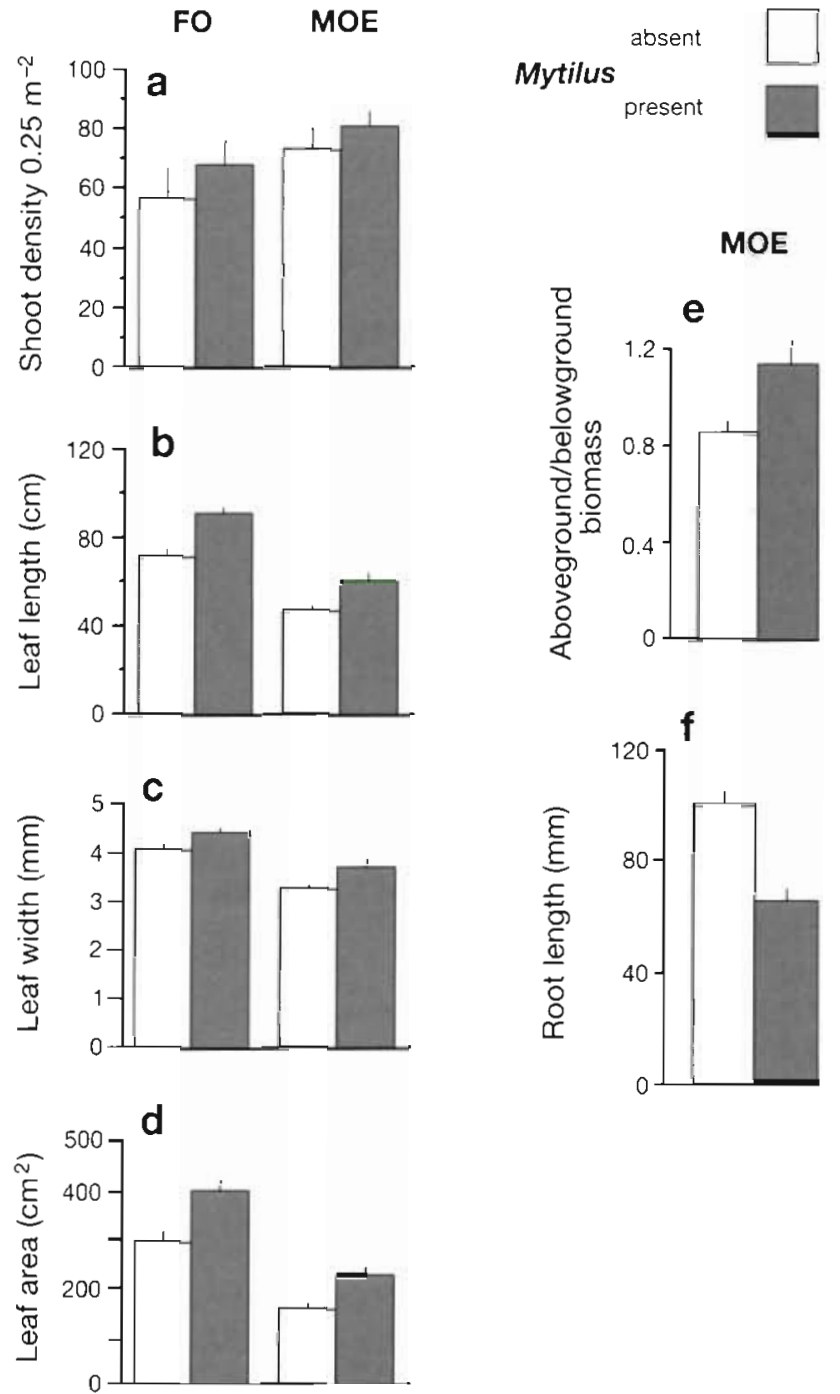

Fig. 5. Zostera manna. Comparison of (a) shoot density, (b) leaf length, (c) leaf width, and (d) leaf area of the largest photosynthetically active leaf of eelgrass in presence and absence of Mytilus edulis at $\mathrm{FO}$ and MOE. Data from destructive core samples at MOE $\left(250 \mathrm{~cm}^{2}\right)$ compare (e) the ratio of aboveground to belowground biomass and (f) the root length of $Z$. marina with the absence/presence of $M$. edulis. Sampling period was between August 25 and September 2, 1993. Sample size was $n=7$ for shoot density. Leaf parameters were determined in 6 haphazardly chosen, adult plants on 7 replicate plots, thus total sample size was $n=42$. (e) Sample size for biomass ratio is 5 . (f) Ten randomly chosen root lengths were determined in 5 core samples, summing up to a total sample size of $n=50$. Error bar is $+1 \mathrm{SE}$. For statistical analysis see Table 1

significantly more ammonium and phosphate than pure Z. marina plots (Fig. 6b, c, Table 1). Since the chance of committing a type I error is increased in the unbalanced phosphate analysis, the significant treatment effect of mussels ( $p=0.0476$ ) has to be interpreted with caution. Nitrate plus nitrite concentrations were 
Table 1. Zostera marina. Summary of observational data on sediment characteristics and on shoot density and plant morphology of Z. marina at 2 sites, FO and MOE, in presence or absence of Mytilus edulis. The following ANOVA models were used: a $2 \times 2$ ANOVA for the shoot densities with Site and $M$. edulis absent/present as factors, and a $2 \times 2$ nested ANOVA with plot nested in both factors, Site and $M$. edulis absent/present, for sediment porewater concentrations (ammonium and phosphate) and for shoot morphology of $Z$. marina (length, width, area of largest leaf). The root lengths of $Z$. marina, at MOE only, were analysed with a 1 -way nested ANOVA with $M$. edulis absence or presence as factor and plot nested in the factor, and the ratio of aboveground to belowground biomass was analysed with a simple 1-way ANOVA. Transformations of the dependent variables are given. After transformation, all data fulfil the Cochran test of homogeneity of variances. Note that 3 samples from different plots were not analysed for phosphate since the sample volume was too small. Therefore, the nested design became unbalanced, i.e. 3 plots contained only 2 instead of 3 replicates. Cochran's test was done with the more conservative value of $G_{(\mathrm{cr})}$ for a group size of $n=3$. For leaf parameters only, the significance level was Bonferroni-adjusted to $\alpha_{\text {adjusted }}=\alpha / 3$ (ns: $p \geq 0.0166 ; \cdot 0.0166>p \geq 0.0033, \cdots 0.0033>p \geq 0.00033$,

$\cdots p<0.00033$ ). All other significance levels are: $n s, p \geq 0.05 ; \cdot 0.05>p \geq 0.01, \cdots 0.01>p \geq 0.001, \cdots p<0.001$

\begin{tabular}{|c|c|c|c|c|c|}
\hline $\begin{array}{l}\text { Dependent variable } \\
\text { Transformation }\end{array}$ & Source of variation & $\mathrm{df}$ & MS & $F$ & $\mathrm{p}$ \\
\hline $\begin{array}{l}\text { Shoot density } \\
x=, y\end{array}$ & $\begin{array}{l}\text { Site } \\
\text { Mytilus absent/present } \\
\text { Site } \times \text { Mytilus absent/present } \\
\text { Error }\end{array}$ & $\begin{array}{r}1 \\
1 \\
1 \\
24\end{array}$ & $\begin{array}{l}6.481 \\
3.060 \\
0.2323 \\
1.4757\end{array}$ & $\begin{array}{l}4.392 \\
2.074 \\
0.1574\end{array}$ & $\begin{array}{l}0.0468 \\
0.1628 \mathrm{~ns} \\
0.6950 \mathrm{~ns}\end{array}$ \\
\hline $\begin{array}{l}\text { Porewater } \\
\text { ammonium } \\
x=3 \cdot y\end{array}$ & $\begin{array}{l}\text { Site } \\
\text { Mytilus absent/present } \\
\text { Site } \times \text { Mytilus absent/present } \\
\text { Plot no. (Site, Mytilus absent/present) } \\
\text { Error }\end{array}$ & $\begin{array}{r}1 \\
1 \\
1 \\
16 \\
40\end{array}$ & $\begin{array}{l}0.4935 \\
9.1693 \\
0.1434 \\
1.1275 \\
0.2364\end{array}$ & $\begin{array}{l}0.4377 \\
8.1321 \\
0.1272 \\
4.7691\end{array}$ & $\begin{array}{l}0.5177 \mathrm{~ns} \\
0.0115^{\prime} \\
0.7260 \mathrm{~ns} \\
0.0001 \cdots\end{array}$ \\
\hline $\begin{array}{l}\text { Porewater } \\
\text { phosphate } \\
x=3 y\end{array}$ & $\begin{array}{l}\text { Site } \\
\text { Mytilus absent/present } \\
\text { Site } \times \text { Mytilus absent/present } \\
\text { Plot no. (Site, Mytilus absent/present) } \\
\text { Error }\end{array}$ & $\begin{array}{r}1 \\
1 \\
1 \\
16 \\
37\end{array}$ & $\begin{array}{l}0.1797 \\
0.3195 \\
0.0004 \\
0.0694 \\
0.0539\end{array}$ & $\begin{array}{l}2.589 \\
4.605 \\
0.0059 \\
1.288\end{array}$ & $\begin{array}{l}0.1272 \mathrm{~ns} \\
0.0476 \\
0.9398 \mathrm{~ns} \\
0.2557 \mathrm{~ns}\end{array}$ \\
\hline $\begin{array}{l}\text { Leaf length } \\
x=\log y\end{array}$ & $\begin{array}{l}\text { Site } \\
\text { Mytilus absent/present } \\
\text { Site } \times \text { Mytilus absent/present } \\
\text { Plot no. (Site, Mytilus absent/present) } \\
\text { Error }\end{array}$ & $\begin{array}{r}1 \\
1 \\
1 \\
24 \\
139\end{array}$ & $\begin{array}{l}1.406 \\
0.468 \\
0.001 \\
0.040 \\
0.009\end{array}$ & $\begin{array}{r}34.984 \\
0.468 \\
0.022 \\
4.486\end{array}$ & $\begin{array}{l}0.0001 \cdots \\
0.0023 \cdots \\
0.8842 \mathrm{~ns} \\
0.0001 \cdots\end{array}$ \\
\hline $\begin{array}{l}\text { Leaf width } \\
x=\log y\end{array}$ & $\begin{array}{l}\text { Site } \\
\text { Mytilus absent/present } \\
\text { Site } \times \text { Mytilus absent/present } \\
\text { Plot no. (Site, Mytilus absent/present) } \\
\text { Error }\end{array}$ & $\begin{array}{r}1 \\
1 \\
1 \\
24 \\
139\end{array}$ & $\begin{array}{l}0.318 \\
0.088 \\
0.002 \\
0.007 \\
0.005\end{array}$ & $\begin{array}{r}48.574 \\
13.405 \\
0.349 \\
1.296\end{array}$ & $\begin{array}{l}0.0001 \cdots \\
0.0012 \cdots \\
0.5601 \mathrm{~ns} \\
0.1774 \mathrm{~ns}\end{array}$ \\
\hline $\begin{array}{l}\text { Leaf area } \\
x=\log y\end{array}$ & $\begin{array}{l}\text { Site } \\
\text { Mytilus absent/present } \\
\text { Site } \times \text { Mytilus absent/present } \\
\text { Plot no. (Site, Mytilus absent/present) } \\
\text { Error }\end{array}$ & $\begin{array}{r}1 \\
1 \\
1 \\
24 \\
139\end{array}$ & $\begin{array}{l}3.061 \\
0.961 \\
0.0003 \\
0.040 \\
3.174\end{array}$ & $\begin{array}{r}76.986 \\
24.182 \\
0.008 \\
1.742\end{array}$ & $\begin{array}{l}0.0001 \cdots \\
0.0001 \cdots \\
0.9276 \mathrm{~ns} \\
0.0252 \mathrm{~ns}\end{array}$ \\
\hline $\begin{array}{l}\text { Root length } \\
x=\log y\end{array}$ & $\begin{array}{l}\text { Mytilus absent/present } \\
\text { Plot no. (Mytilus absent/present) } \\
\text { Error }\end{array}$ & $\begin{array}{r}1 \\
8 \\
90\end{array}$ & $\begin{array}{l}0.9682 \\
0.0813 \\
0.0206\end{array}$ & $\begin{array}{c}11.902 \\
3.9394\end{array}$ & $\begin{array}{l}0.0087 \cdots \\
0.0005 \cdots\end{array}$ \\
\hline $\begin{array}{l}\text { Aboveground to below- } \\
\text { ground biomass ratio } \\
\text { (no transformation) }\end{array}$ & $\begin{array}{l}\text { Mytilus absent/present } \\
\text { Error }\end{array}$ & $\begin{array}{l}1 \\
8\end{array}$ & $\begin{array}{l}0.3133 \\
0.0293\end{array}$ & 10.693 & $0.114 \mathrm{~ns}$ \\
\hline
\end{tabular}

always at the detection limit $(<1 \mu \mathrm{M})$. As can be expected in reduced sediments, they contribute very little to the total inorganic nitrogen available to the rhizosphere of Z. marina and were therefore excluded from further data analysis.

Regression between sediment nutrient concentration and growth. Plotting the ammonium porewater concentrations against leaf length results in a saturation-type, hyberbolic function which levels off at approximately $75 \mu \mathrm{M}$ ammonium at MOE and $100 \mu \mathrm{M}$ at $\mathrm{FO}$ (Fig. 7a). The calculated regression equation according to a Monod model explains $71 \%$ and $34 \%$ of the variation in leaf length at $M O E$ and $F O$, respectively. The ANOVAs on the Woolf linearized data were 


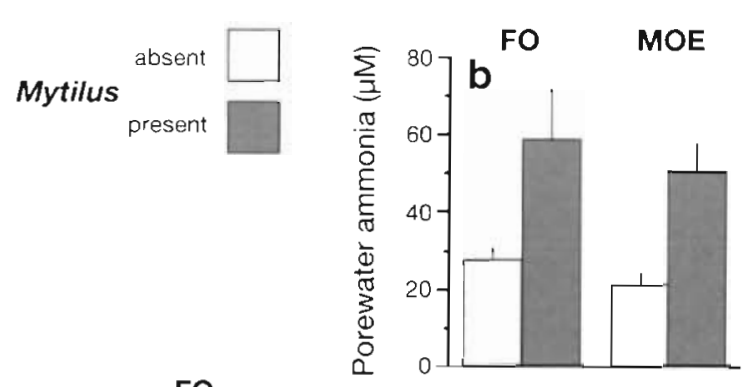

FO
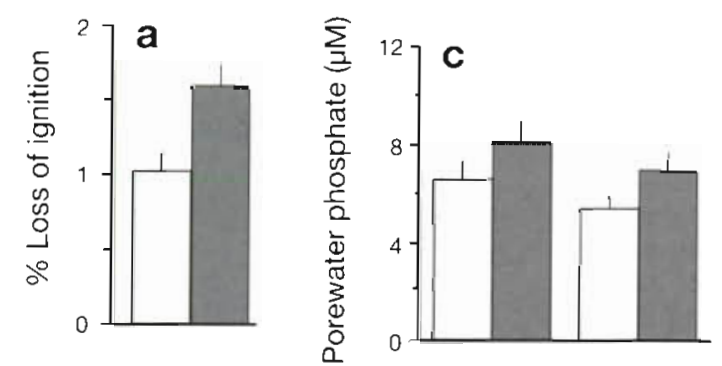

Fig. 6. Zostera marina, Mytilus edulis. Sediment parameters on eelgrass plots in absence and presence of blue mussels at Friedrichsort ( $\mathrm{FO}$ ) and Möltenort (MOE). Mean (+ $1 \mathrm{SE}$ ) of (a) loss of ignition LOI, (b) sediment porewater concentration of ammonium, and (c) of soluble reactive phosphate (SRP) are shown. Three subsamples were taken in 7 plots for determination of organic content (LOI), thus total sample size was $n=21$; triplicate porewater subsamples were taken on 5 plots, thus the total sample size was $n=15$ for porewater phosphate and ammonium. For statistical analysis of data see Table 1

highly significant for both sites (at FO $\mathrm{p}=0.00004$, at MOE $p<0.00001$; Fig. 7b).

In contrast to ammonium, no such relationship exists between porewater phosphate concentrations and the leaf length of Zostera marina (Fig. 7c). Except for 3 higher values, all concentrations are found within a range of 3 to $11 \mu \mathrm{M}$ soluble reactive phosphate in the porewater. No regression formula was calculated because of this obvious lack of correlation

Observations on Zostera/Mytilus borders. There was no evident effect of adjacent Mytilus edulis patches on the vegetative propagation of Zostera marina when analysing the propagation distances with a 1-way ANOVA with plot nested in border type (Fig. 8, Table 2). Furthermore, $Z$. marina did not propagate faster when co-occurring with $M$. edulis. There was a considerable variation among the sampled plots which were nested within one border type. This was largely due to the irregular shape of the propagating meadow edge. Hence within one plot, some propagation distances were zero while other rhizomes propagated some $30 \mathrm{~cm}$. However, absolute propagation rates were very similar among levels of the factor 'border' $(n=40$, mean propagation \pm SE from April 4 to October 18 ,
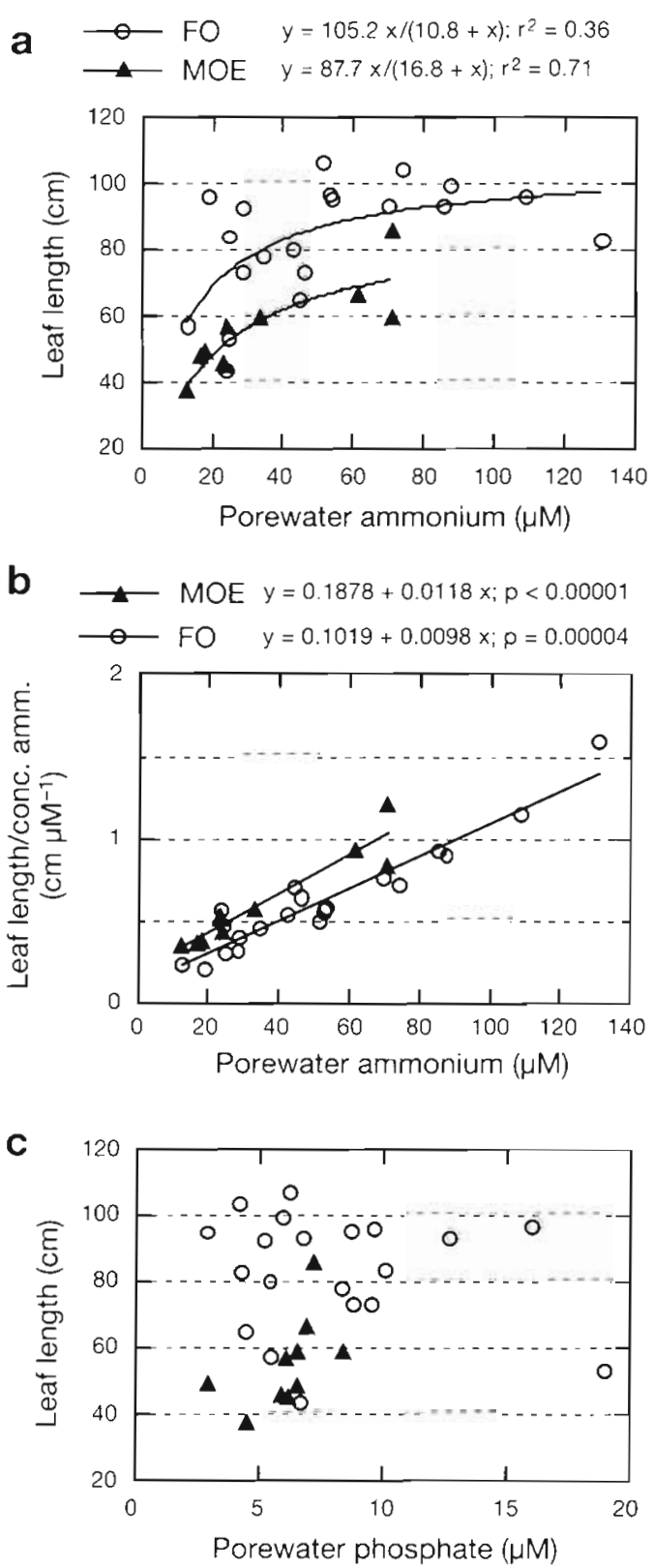

Fig. 7. Zostera marina. Leaf lengths of Zostera measured between August 26 and September 2, 1993 as function of the ammonium $(a, b)$ and phosphate concentrations (c) in the sediment porewater at Stns FO and MOE on unmanipulated plots. Half of them had a Mytilus edulis understory. For ammonium, the corresponding Monod equation was determined by a least-square approximation and is given (a) (b) Woolf linear transformation of the data in (a). The significance of the linear plot was checked by ANOVA. Their $p$-values are given. Each data point represents the mean of 3 nutrient determinations and 6 leaf measurements. No equation or linearization was calculated for phosphate because of the apparent lack of correlation.

1993: Zostera/Mytilus into $M$. edulis $13.27 \pm 0.96 \mathrm{~cm}$, Zostera/Mytilus into sand $14.6 \pm 1.45 \mathrm{~cm}, Z$. marina into sand $13.3 \pm 1.50 \mathrm{~cm}$ ). 


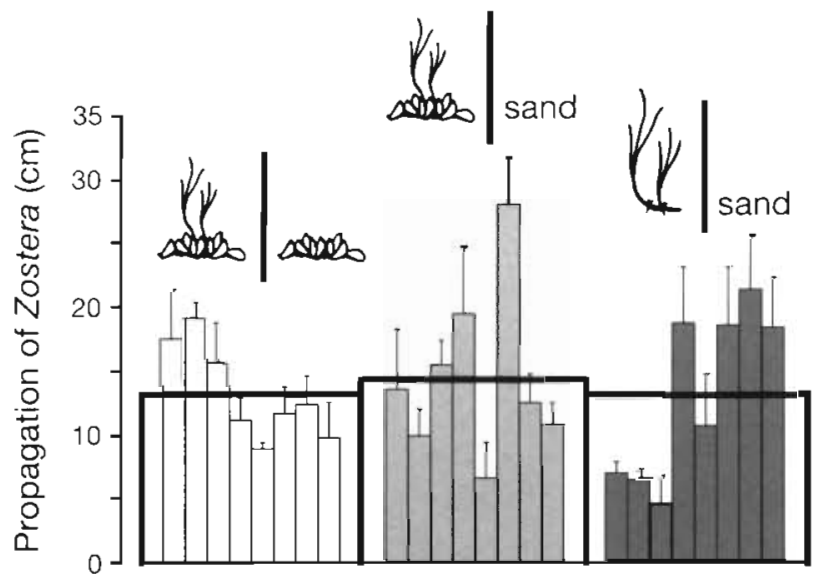

Fig. 8. Zostera marina, Mytilus edulis. Comparison of the vegetative propagation of different borders of eelgrass patches over 6 mo. In each of the 8 independent replicate plots on one border type, 5 propagation distances of the meadow edge were randomly obtained between the position of the patch border on April 4 and on October 18, 1993. Total no. of samples per border type is 8 replicates $\times 5$ distances per replicate $=40$. Means $(+1$ SE) of the replicate plots are shown separately to emphasize the considerable scatter within one border type. The unfilled large blocks represent the overall means for one border type. Their SEs are given in the text See Table 2 for statistical analysis

\section{Experiments}

Experimental effects of Mytilus edulis on Zostera marina density. The Mytilus edulis addition/removal experiment showed no negative influence of $M$. edulis on Zostera marina density (Fig. 9a, b). Neither the addition of $M$. edulis to $Z$. marina patches nor the removal of mussels from existing Zostera/Mytilus associations resulted in significant changes of $Z$. marina shoot density at the final sampling date. The results of the analyses are summarized in Table $3(M$. edulis addition experiment) and Table 4 ( $M$. edulis removal

Table 2. Zostera marina, Mytilus edulis. One-way nested ANOVA comparing the vegetative propagation of $Z$. marina patches from April 4 to October 18, 1993, among 3 different border types: (1) Zostera/Mytilus association propagating into M. edulis, (2) Zostera/Mytilus association propagating into bare sand, and (3) $Z$. marina propagating into bare sand. Five distances between the April and October border positions obtained at random in each replicate plot were nested in factor border type. Distances were $(\log +1)$-transformed to fulfil Cochran's test of homogeneity of variances. Significance as in Table 1

\begin{tabular}{|lrccc|}
\hline Source of variation & df & MS & $F$ & $p$ \\
\hline Border type & 2 & 0.062 & 0.266 & 0.7689 ns \\
Sample no. & 21 & 0.233 & 3.022 & $0.0001 \cdots$ \\
Error & 96 & 0.077 & & \\
& & & & \\
\hline
\end{tabular}

experiment). Both ANCOVAs detected no significant difference in shoot density on the final sampling date (October 27). None of the interactions between initial density and $M$. edulis absent/present were significant, i.e. the ANCOVAs were legitimate.

Both MANOVAs revealed that there was also no effect of Mytilus edulis on Zostera marina density throughout the whole experimental period (April to October)

Before manipulation on April 10, the 10 Zostera/ Mytilus plots of the $M$. edulis removal experiment showed a trend of having a higher shoot density compared to the pure $Z$. marina plots before manipulation (1-way ANOVA, shoot density square-root-transformed $\left.\mathrm{n}=10, F_{(1,18)}=3.199, \mathrm{p}=0.0905\right)$. However, this difference was not consistent with the outcome of a

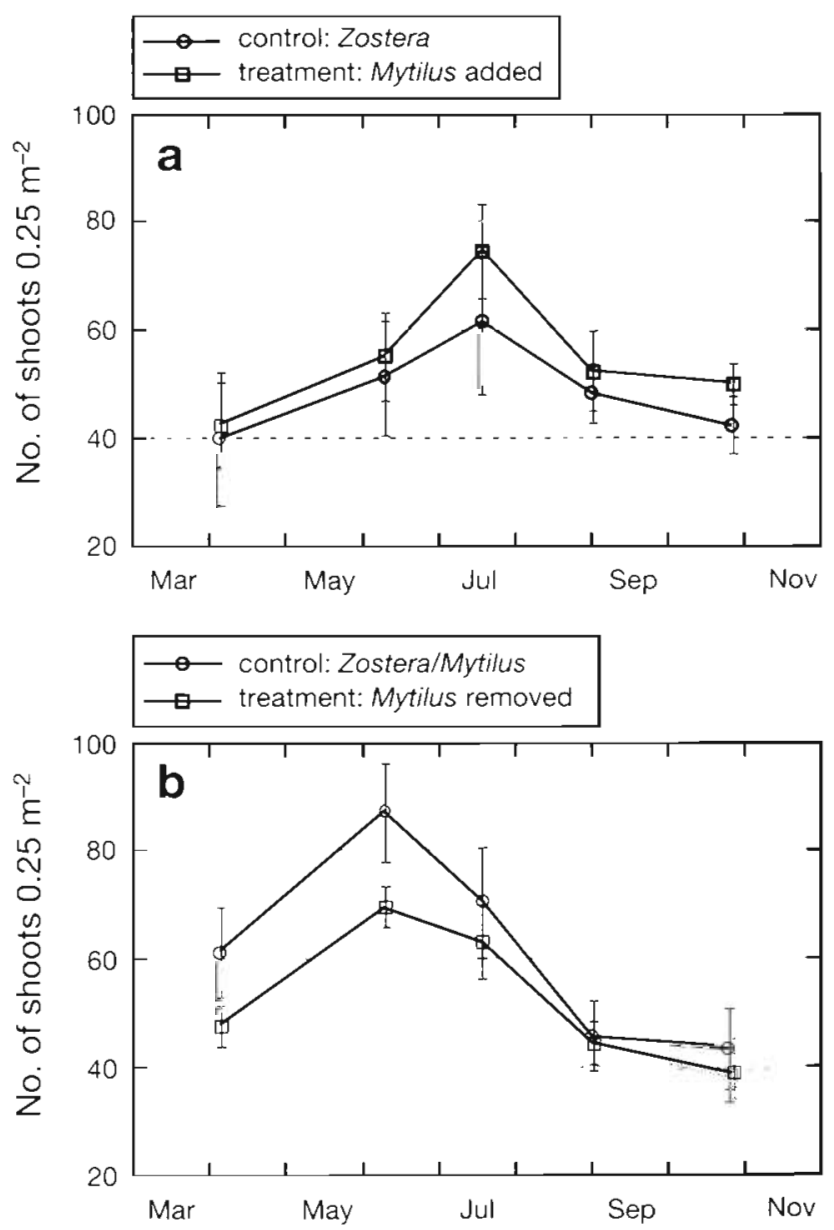

Fig. 9. Zostera marina, Mytilus edulis. Eelgrass densities in $50 \times 50 \mathrm{~cm}^{2}$ during 1 growth period from April 10 to October 27, 1993. The experimental effects of (a) the addition of $M$. edulis to $Z$. marina plots and (b) the removal of $M$. edulis from Zostera/Mytilus association plots on density of $Z$. marina are shown compared to the unmanipulated controls. Values were obtained at approximately 6 weekly intervals and are means ( $\pm 1 \mathrm{SE}$ ) of 5 replicates. For statistical analysis see Tables $3 \& 4$ 
Table 3. Zostera marina, Mytilus edulis. Univariate analysis of covariance (ANCOVA) and multivariate analysis of variance (MANOVA) on the effect of blue mussel addition on eelgrass shoot density. The ANCOVA tests if shoot densities are different on the final sampling date (October 27), taking into account the initial, post-manipulative shoot density as covariate. A test of homogeneity of slopes was done prior to the analysis. In the MANOVA, the 4 post-manipulative sampling dates (June 2, July 21, September 2, October 27, 1993) were treated as 1 dependent vector. Shoot numbers as response variable, as well as the initial density in the case of the ANCOVA, were square-root transformed to remove heterogeneity of variances. The univariate data fulfil Cochran's test of homogeneity of variances and the multivariate data fulfil a modified Hawkin's test of multi-normality and -homoscedasticity (Johnson \& Field 1993). Significance as in Table 1

\begin{tabular}{|c|c|c|c|c|c|}
\hline Analysis & Source of variation & df & MS & $F$ & $\mathrm{p}$ \\
\hline Homogeneity of slopes & $\begin{array}{l}\text { Initial density } \times \text { Mytilus absent } / \text { present } \\
\text { Error }\end{array}$ & $\begin{array}{l}1 \\
6\end{array}$ & $\begin{array}{l}0.157 \\
0.356\end{array}$ & 0.442 & $0.531 \mathrm{~ns}$ \\
\hline ANCOVA & $\begin{array}{l}\text { Initial density } \\
\text { Mytilus absent/present } \\
\text { Error }\end{array}$ & $\begin{array}{l}1 \\
1 \\
7\end{array}$ & $\begin{array}{l}2.471 \\
0.536 \\
0.327\end{array}$ & $\begin{array}{l}7.551 \\
1.637\end{array}$ & $\begin{array}{l}0.029^{\circ} \\
0.241 \mathrm{~ns}\end{array}$ \\
\hline Analysis & Source of variation & $F$ & Hyp. df & Error df & $\mathrm{p}$ \\
\hline MANOVA & Mytilus absent/present & 0.473 & 4 & 5 & $0.756 \mathrm{~ns}$ \\
\hline
\end{tabular}

MANOVA, considering the shoot densities in the control plots on all 5 sampling dates as dependent variables. This analysis rejected the hypothesis that Z. marina has a higher density in the presence of $M$. edulis during the entire growth period (1-way MANOVA, Pillai Trace $\left.=0.829, F_{(5,4)}=3.889, \mathrm{p}=0.106\right)$. These results are in concordance with the observational data on shoot densities described above (Fig. 5a, Table 1).

Effects of Mytilus edulis on Zostera marina leaf morphology and porewater nutrient concentrations. As a consequence of the experimental treatment, all measured characteristics of plant morphology, i.e. the length, width and area of the largest leaf, changed significantly (Fig. 10c, e, Tables 5 \& 6). Where Mytilus edulis was added, the leaf area increased by $35 \%$ compared to Zostera/Mytilus control plots, and this is almost precisely the difference in plant size in similarly configured unmanipulated plots at $\mathrm{FO}$ (leaf area is $36 \%$ higher with $M$. edulis at $\mathrm{FO}$, and $48 \%$ at MOE, respectively; Fig. 10e). The removal of $M$. edulis revealed a smaller effect: the decrease in leaf area in mussel-free plots was only $16 \%$ and the decrease in leaf width not significant at all (Fig. 10d, e, Table 6).

Observational differences in sediment nutrient characteristics and plant morphology between Zostera marina stands with and without an understory of mussels are in concordance with the experimental results. The porewater concentrations of both ammonium and phosphate almost doubled after the addition of mussels (Fig. 10a, b). The removal of mussels caused the phosphate concentrations to decrease in the manipulated plots. Only for porewater ammonium in the Mytilus edulis removal experiment, did we fail to detect a significant difference between plots with and without M. edulis (Fig. 10a, Table 6)

Table 4. Zostera marina, Mytilus edulis. Separate univariate analysis of covariance (ANCOVA) and multivariate analysis of variance (MANOVA) on the effect of $M$. edulis removal on $Z$. marina shoot density on the last sampling date only in case of the ANCOVA, and on all 4 sampling dates during the growth period (June 2, July 21, September 2, October 27, 1993) in the case of the MANOVA. For further details see Table 3 ; significance as in Table 1

\begin{tabular}{|c|c|c|c|c|c|}
\hline Analysis & Source of variation & $\mathrm{df}$ & MS & $F$ & $\mathrm{p}$ \\
\hline \multirow[t]{2}{*}{ Homogeneity of slopes } & \multirow{2}{*}{$\begin{array}{l}\text { Initial density } \times \text { Mytilus absent/present } \\
\text { Error }\end{array}$} & 1 & 0.003 & 0.004 & $0.953 \mathrm{~ns}$ \\
\hline & & 6 & 0.798 & & \\
\hline \multirow[t]{3}{*}{ ANCOVA } & \multirow{3}{*}{$\begin{array}{l}\text { Initial density } \\
\text { Mytilus absent/present } \\
\text { Error }\end{array}$} & 1 & 4.377 & 6.398 & $0.039^{\circ}$ \\
\hline & & 1 & 0.216 & 0.316 & 0.592 ns \\
\hline & & 7 & 0.684 & & \\
\hline Analysis & Source of variation & $F$ & Hyp. df & Error df & $\mathrm{p}$ \\
\hline MANOVA & Mytilus absent/present & 0.425 & 4 & 5 & $0.501 \mathrm{~ns}$ \\
\hline
\end{tabular}



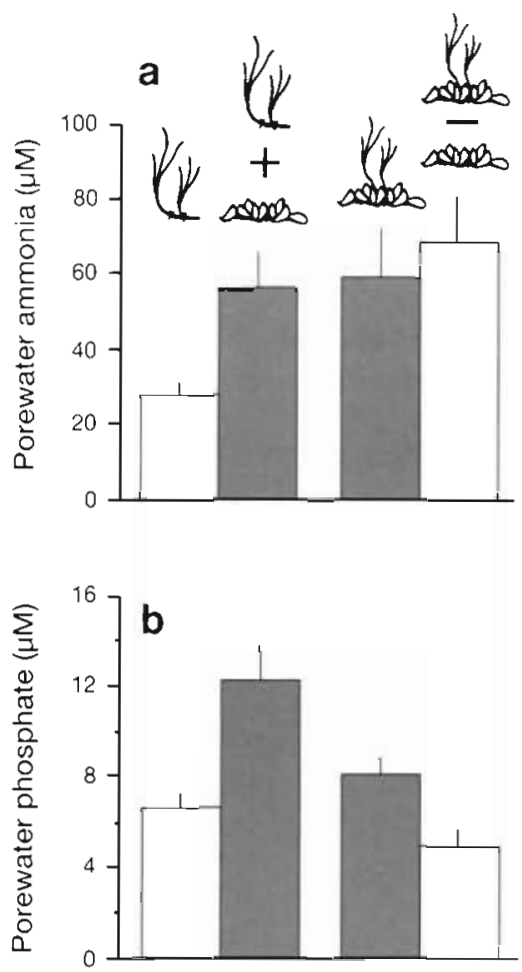

Fig. 10. Zostera marina, Mytilus edulis. Effects of experimental addition and removal of $M$. edulis on (a) sediment porewater concentrations of ammonium and (b) phosphate compared to unmanipulated controls, and (c to e) leaf parameters of Zostera. Measurements of plant morphology and sediment porewater were done between August 26 and 28, 1993. Triplicate sediment samples were taken and 6 adult plants were measured in each plot, thus sample size was $n=15$ for porewater analysis and $n=30$ for leaf morphology. Error bar is $+1 \mathrm{SE}$. See Tables $5 \& 6$ for statistical analysis of data

Thus, the Mytilus edulis addition/removal experiment provides evidence that the morphology of individual plants is in fact dependent on the presence or absence of mussels and not on an unknown covarying factor, and that in addition, sediment characteristics are altered by the presence of $M$. edulis.

\section{DISCUSSION}

\section{Competition}

The experimental results concerning the change of Mytilus edulis densities, as well as field observations, showed no negative effect of mussels on the shoot density and plant morphology of Zostera marina. This also holds true for the vegetative propagation of $Z$. marina patch margins which are not influenced by the presence of an adjacent mussel patch. The rate of the margin projection into bare sand compared to projection into Mytilus edulis patches during 1 growth period showed only small, non-significant differences.
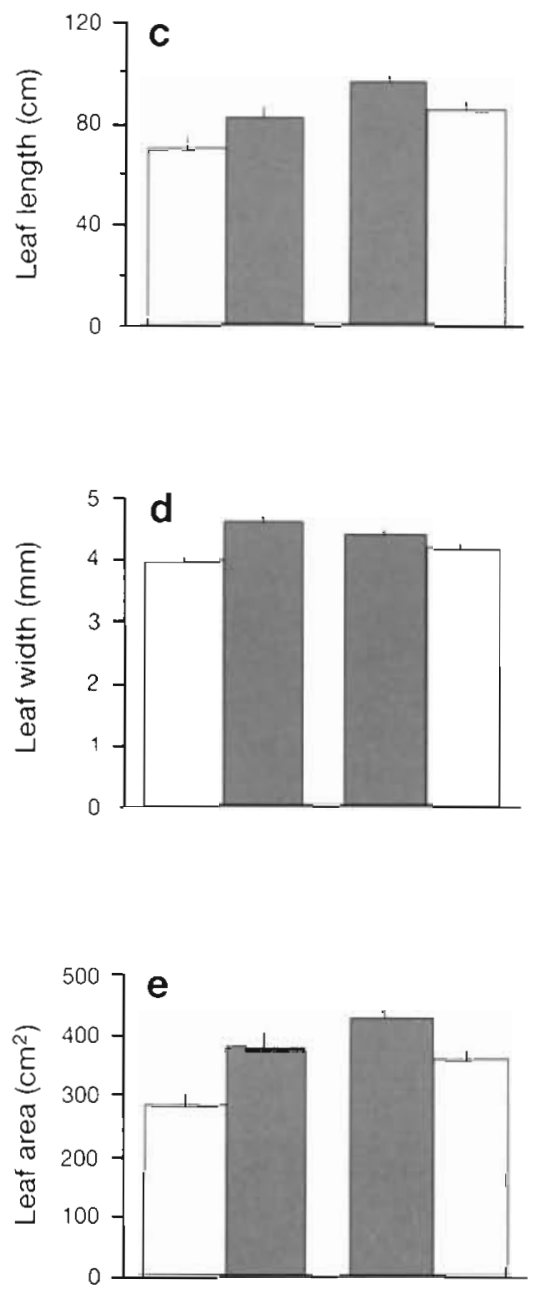

Why is it that interference competition between mussels and the co-occuring macrophyte Zostera marina does not occur? In fact, spatial competition has seldom been found to structure soft-bottom communities. The key to these community regulation differences between soft and hard bottom lies in the mechanisms by which mussels may competitively exclude macroalgae or sessile organisms. Peterson (1979) distinguishes 2 principal mechanisms of interference competition on hard substrata: (1) heavy settlement and overgrowth and subsequent suffocation and starvation of the overgrown organisms; and (2) direct interference by crushing or prying other organisms off the surface of the primary substratum. Despite heavy settlement of Mytilus edulis plantigrades in summer 1992 and 1993 (pers. obs.), Mechanism 1 was not observed during the study period in Kiel Fjord or in the adjacent Kiel Bight at several subtidal stations. Direct interference is rare according to Peterson (1979), since on soft bottoms, competitively inferior organisms may easily find a spatial refuge from competition in the 3-dimensional space which is available. 
Table 5. Zostera marina, Mytilus edulis. One-way ANOVA (with blocking factor) on the effects of experimental addition of $M$. edulis to $Z$. marina patches on nutrient concentrations of sediment porewater and on morphology of the largest photosynthetically active leaf of $Z$. marina. The Block $\times$ Treatment interactions were tested in advance and are not shown. None of them was significant. After transformation, which is given below, all dependent variables fulfil Cochran's test for homogeneity of variances. Note that 3 samples from different plots were not analysed for phosphate. Thus, the design became unbalanced, i.e. 3 experimental plots had only 2 replicates. This increases the chance of committing a type I error. Nevertheless, the analysis is shown since the outcome is highly significant. The Cochran test was performed with a $G_{\text {(crit) }}$ for a group size of $n=3$. For leaf parameters only, the significance level was Bonferroni-adjusted to $\alpha_{\text {adjusted }}=\alpha / 3$ (ns: $p \geq 0.0166 ; \cdot 0.0166>p \geq 0.0033, \cdots 0.0033>p \geq$

$0.00033, \cdots p<0.00033$ ). All other significance levels are: $n s, p \geq 0.05 ; \cdot 0.05>p \geq 0.01, \cdots 0.01>p \geq 0.001, \cdots p<0.001$

\begin{tabular}{|c|c|c|c|c|c|}
\hline $\begin{array}{l}\text { Dependent variable } \\
\text { Transformation }\end{array}$ & Source of variation & $\mathrm{df}$ & MS & $F$ & $\mathrm{p}$ \\
\hline $\begin{array}{l}\text { Porewater ammonium } \\
x=\log y\end{array}$ & $\begin{array}{l}\text { Mytilus absent/present } \\
\text { Block } \\
\text { Error }\end{array}$ & $\begin{array}{r}1 \\
4 \\
24\end{array}$ & $\begin{array}{l}0.6271 \\
0.0373 \\
0.0510\end{array}$ & $\begin{array}{l}12.30 \\
0.7305\end{array}$ & $\begin{array}{l}0.0018 \cdots \\
0.5800 \mathrm{~ns}\end{array}$ \\
\hline $\begin{array}{l}\text { Porewater phosphate } \\
x=\log y\end{array}$ & $\begin{array}{l}\text { Mytilus absent/present } \\
\text { Block } \\
\text { Error }\end{array}$ & $\begin{array}{r}1 \\
4 \\
21\end{array}$ & $\begin{array}{l}0.4053 \\
0.0593 \\
0.381\end{array}$ & $\begin{array}{r}10.643 \\
1.558\end{array}$ & $\begin{array}{l}0.0037^{\bullet} \\
0.2223 \mathrm{~ns}\end{array}$ \\
\hline $\begin{array}{l}\text { Leaf length } \\
x=\log y\end{array}$ & $\begin{array}{l}\text { Mytilus absent/present } \\
\text { Block } \\
\text { Error }\end{array}$ & $\begin{array}{r}1 \\
4 \\
54\end{array}$ & $\begin{array}{l}0.0917 \\
0.1514 \\
0.0097\end{array}$ & $\begin{array}{l}9.431 \\
15.58\end{array}$ & $\begin{array}{l}0.0033 \cdots \\
0.0001 \cdots\end{array}$ \\
\hline $\begin{array}{l}\text { Leaf width } \\
x=\log y\end{array}$ & $\begin{array}{l}\text { Mytilus absent/present } \\
\text { Block } \\
\text { Error }\end{array}$ & $\begin{array}{r}1 \\
4 \\
54\end{array}$ & $\begin{array}{l}0.0490 \\
0.0016 \\
0.0044\end{array}$ & $\begin{array}{l}11.25 \\
0.3767\end{array}$ & $\begin{array}{l}0.0015 \cdots \\
0.8243 \mathrm{~ns}\end{array}$ \\
\hline $\begin{array}{l}\text { Leaf area } \\
x=\log y\end{array}$ & $\begin{array}{l}\text { Mytilus absent/present } \\
\text { Block } \\
\text { Error }\end{array}$ & $\begin{array}{r}1 \\
4 \\
54\end{array}$ & $\begin{array}{l}0.2747 \\
0.1731 \\
0.0219\end{array}$ & $\begin{array}{c}12.52 \\
7.889\end{array}$ & $\begin{array}{l}0.0008 \cdots \\
0.0001 \cdots\end{array}$ \\
\hline
\end{tabular}

However, the community studied differs from a true soft-bottom situation because both organisms are restricted wholly (Mytilus edulis) or partially (Zostera marina) to the 2-dimensional sediment surface. Thus, available space is reduced to 2 dimensions. This increases the likelihood for space to become a limiting resource compared to endobenthic, 3-dimensional soft-bottom communities. In this respect, the

Table 6. Zostera marina, Mytilus edulis. One-way ANOVA (with blocking factor) on the effects of removal of $M$. edulis from Zostera/Mytilus associations on nutrient concentrations in the sediment porewater and on the morphology of the largest photosynthetically active leaf of $Z$. marina. Only for leaf width was there a significant Block $\times$ Treatment interaction ( $p=0.0497$ ). Note that the design is unbalanced for phosphate data, since 2 samples from 2 different plots were not analyzed. See Table 5 for further details. Significance as in Table 1

\begin{tabular}{|c|c|c|c|c|c|}
\hline $\begin{array}{l}\text { Dependent variable } \\
\text { Transformation }\end{array}$ & Source of variation & $\mathrm{df}$ & MS & $F$ & $\mathrm{p}$ \\
\hline $\begin{array}{l}\text { Porewater ammonium } \\
x=\sqrt[3]{y} y\end{array}$ & $\begin{array}{l}\text { Mytilus absent/present } \\
\text { Block } \\
\text { Error }\end{array}$ & $\begin{array}{r}1 \\
4 \\
24\end{array}$ & $\begin{array}{l}0.6077 \\
3.3065 \\
0.3956\end{array}$ & $\begin{array}{l}1.5361 \\
8.3575\end{array}$ & $\begin{array}{l}0.2272 \mathrm{~ns} \\
0.0002 \cdots\end{array}$ \\
\hline $\begin{array}{l}\text { Porewater phosphate } \\
x=\log y\end{array}$ & $\begin{array}{l}\text { Mytilus absent/present } \\
\text { Block } \\
\text { Error }\end{array}$ & $\begin{array}{r}1 \\
4 \\
22\end{array}$ & $\begin{array}{l}0.4645 \\
0.0757 \\
0.0254\end{array}$ & $\begin{array}{c}18.274 \\
2.9794\end{array}$ & $\begin{array}{l}0.0003 \cdots \\
0.0416 \cdots\end{array}$ \\
\hline $\begin{array}{l}\text { Leaf length } \\
x=\log y\end{array}$ & $\begin{array}{l}\text { Mytilus absent/present } \\
\text { Block } \\
\text { Error }\end{array}$ & $\begin{array}{r}1 \\
4 \\
54\end{array}$ & $\begin{array}{l}0.0546 \\
0.0401 \\
0.0065\end{array}$ & $\begin{array}{l}8.414 \\
6.183\end{array}$ & $\begin{array}{l}0.0054^{\circ} \\
0.0004^{\cdots}\end{array}$ \\
\hline $\begin{array}{l}\text { Leaf width } \\
x=\log y\end{array}$ & $\begin{array}{l}\text { Mytilus absent/present } \\
\text { Block } \\
\text { Error }\end{array}$ & $\begin{array}{r}1 \\
4 \\
54\end{array}$ & $\begin{array}{l}0.0048 \\
0.0029 \\
0.0028\end{array}$ & $\begin{array}{l}1.756 \\
1.051\end{array}$ & $\begin{array}{l}0.1907 \mathrm{~ns} \\
0.3995 \mathrm{~ns}\end{array}$ \\
\hline $\begin{array}{l}\text { Leaf area } \\
x=\log y\end{array}$ & $\begin{array}{l}\text { Mytilus absent/present } \\
\text { Block } \\
\text { Error }\end{array}$ & $\begin{array}{r}1 \\
4 \\
54\end{array}$ & $\begin{array}{l}0.0920 \\
0.0397 \\
0.0129\end{array}$ & $\begin{array}{l}7.147 \\
3.083\end{array}$ & $\begin{array}{l}0.0099^{\circ} \\
0.0233 \mathrm{~ns}\end{array}$ \\
\hline
\end{tabular}


Zostera/Mytilus association represents an intermediate between a true soft-bottom and a hard-bottom situation. Moreover, mussels are known to suppress the growth of conspecifics if occurring in beds or clumps, not only by competition for food, but also via spatial competition (Harger 1972, Bertness \& Grossholz 1985, Fréchette \& Lafaivre 1990). To do this, they need not be anchored to a primary rocky substrate. Therefore, squeezing and crushing of $Z$. marina shoots may be a potential mechanism by which mussels affect eelgrass (Fig. 1b).

Direct interference of Zostera marina by mussels was observed by Ruth (1991, pers. comm.) in intertidal $Z$. marina meadows of the Wadden Sea and by Kobarg (1993) who transplanted $Z$. marina in boxes to greater water depths to study the effects of light limitation. While the situation in the Wadden Sea may be completely different from the Baltic, our results seem to contradict Kobarg's observations. Interference competition by mussels squeezing the shoots of $Z$. marina seems only plausible if space is limiting and mussel patches cannot extend further. We believe that this was the case in Kobarg's experiments, since the mussels covered the experimental plots completely and attached to the edges of the plastic boxes. The forces they could exert on the shoots were higher compared to mussel patches which have the possibility of extending towards sandy edges (Fig. 1a). Instead, space for epibenthic plants or animals is never limiting in the depth range investigated. Approximately $50 \%$ of the area at FO and $60 \%$ at MOE consists of bare sand devoid of $Z$. marina and Mytilus edulis (Fig. 3).

The ultimate reason for a lack of interference competition may be the frequent biological and physical disturbance of mussel patches which never let coverage by mussels increase beyond $20 \%$. The recruitment of Mytilus edulis and hence patch extension is primarily controlled by predation from the seastar Asterias rubens, whereas physical disturbance is the main source of mortality for mussel adults (Reusch \& Chapman unpubl.) During the winter 1992-1993, most of the marked pure mussel patches neighbouring Zostera/Mytilus patches were destroyed by storms (pers. abs.). Furthermore, in 4 out of 8 marked Zostera/Mytilus patches, mussels were washed away while $Z$. marina remained intact. As a consequence, mussel patches inside or outside eelgrass meadows rarely attained a size larger than $2 \mathrm{~m}$ diameter. We assume that this is below the limit at which forces exerted by the cumulative growth of $M$. edulis individuals harm eelgrass shoots.

Although several studies showed that mytilid mussels interfere with macroalgae (Dayton 1971, Paine 1974 for Mytilus californianus; Paine 1971 for Perna canaliculus; Menge 1976 for $M$. edulis), there is recent experimental evidence that $M$. edulis is not competitively superior to fucoid algae on North Atlantic rocky shores (Janke 1990, McCook \& Chapman 1991).

It may be questioned whether the time scale, i.e. 1 growth period from spring to autumn, is sufficient to exclude the possibility of competition occurring between mussels and eelgrass over a longer period. We found no evidence for this, since none of the above mentioned 4 Zostera/Mytilus plots, in which Mytilus coverage survived the winter storms, developed into a pure mussel bank over a period of $17 \mathrm{mo}$.

\section{Fertilization of Zostera marina}

Instead of damaging eelgrass, mussels have a positive effect on Zostera marina growth. The mechanism of this facilitation is the biodeposition of nutrient-rich material by the mussels onto the sediment surface. The mineralization of the organic material increases the amount of nutrients available to the rhizosphere of Z. marina.

The significant differences in plant morphology and size which were produced by the experimental removal and addition of mussels give strong evidence that Mytilus edulis, and not an unknown covarying factor, is responsible for an increased growth of Zostera marina. Although actual growth rates were not measured due to time constraints, we believe it to be legitimate to correlate plant morphology with growth because the experimental blocks were chosen to be as homogeneous as possible. Therefore, we assume that in April, all plants started to grow from the same average size.

It is well known that leaf morphology is a function of the nutrient conditions to which Zostera marina is exposed (Short 1983b). Plants are smaller and the leaves are narrower under nutrient deficiency (Philip 1936, Short 1987). The ratio between aboveground and belowground biomass becomes smaller and the length of the roots increases (Barko et al. 1991). All these morphological characteristics are concordant with the results of the present study and we conclude that growth of $Z$. marina is nutrient limited in Kiel Fjord.

The responses of shoot densities to nutrient enrichment vary in the literature. Whereas Short (1983b) found a significantly higher shoot density in nutrientpoor sediments, Orth (1977) observed increased density after experimental fertilization of Zostera marina. Our data indicate no effect of higher sediment nutrient levels on the density of $Z$. marina.

There is an ongoing debate concerning the relative importance of nitrogen vs phosphorus limitation in seagrasses. Growth was found to be nitrogen limited 
in several studies (Short 1983a, b, Williams \& Ruckelshaus 1993). However, Murray et al. (1992) reported increased growth in Zostera marina after phosphorus addition to the sediment. Our data indicate that nitrogen is limiting for eelgrass growth on the organically poor sediments of the very shallow subtidal ( 1 to $2.5 \mathrm{~m}$ depth) of Kiel Fjord. We infer this from the lack of a correlation between porewater phosphate concentration and leaf lengths in this study, indicating that phosphate is of minor importance.

The saturation concentrations for porewater ammonium $(75 \mu \mathrm{M}$ in $\mathrm{FO}$ and $100 \mu \mathrm{M}$ in $\mathrm{MOE})$, which were derived graphically from the calculated regression equations, fall well within the range of concentrations documented for growth saturation of Zostera marina in the literature (Short \& McRoy 1984, Dennison et al. 1987, Williams \& Ruckelshaus 1993). These concentrations of porewater ammonium are never encountered at MOE and very seldom at FO.

Recently, Pedersen \& Borum (1993) fertilized a Baltic Zostera marina population with a combined $\mathrm{N}: \mathrm{P}: \mathrm{K}$ fertilizer. In a non-replicated experiment, they found a moderate, but significant ( $7 \%$ to $24 \%$ ) increase in leaf elongation rate in fertilized plots compared to control plants. Since, during summer, the sediments of their study site had a markedly higher ammonium concentration in porewater than our sediments $(240$ to $300 \mu \mathrm{M}$ compared to 17 to $110 \mu \mathrm{M}$ at FO and 16 to $70 \mu \mathrm{M}$ at MOE) a nitrogen limitation of $Z$. marina growth in the Kiel Fjord is very likely.

The removal of Mytilus edulis from Zostera/Mytilus associations showed a smaller effect on plant parameters compared to the addition treatment (Fig. 10c to e). Where $M$. edulis was experimentally removed, plants attained a larger size than those in $Z$. marina control plots. This suggests the presence of a pool of biodeposited organic matter in the sediment which mineralizes over a longer period and continues to fertilize $Z$. marina for some weeks after mussel removal. In the $M$. edulis addition treatment, the direct excretion of ammonium and the production of rapidly degradable biodeposits by mussels starts immediately after the addition.

If Mytilus edulis occurrence is a major source of variation in the sediment nutrient status and, as a consequence, for plant morphology, the high plot-to-plot variability among Zostera marina as well as Zostera/ Mytilus patches may reflect the history of a patch. It is probable that pure $Z$. marina patches with relatively large plants once had a $M$. edulis understory for a certain time before mussels were washed away by winter storms. Likewise, in Zostera/Mytilus patches having small plants, $Z$. marina may exist in association and thus under nutrient enrichment for a few weeks only. Storms not only destroy associations, but can change a
Z. marina patch within a few hours into an association through drifting adult mussel clumps. They are as important for the formation of Zostera/Mytilus associations as is mussel recruitment (Reusch \& Chapman unpubl.).

Similarly, the high rate of mussel patch fluctation may have influenced the comparison of propagation rates. In contrast to studies of Kenworthy \& Fonseca (1977) and Williams (1990) who reported that the rate of seagrass colonization of bare sand is accelerated with fertilization, we were not able to detect differences in propagation rates among Mytilus edulis fertilized eelgrass and pure eelgrass stands. One possible explanation is that time delay between fertilization and plant response in the form of increased vegetative sprouting is longer than 1 vegetation period. Since patch fluctuation of mussel beds is high at both sites, the time period of co-occurrence with mussels of the selected Zostera marina patches may be too short to detect a response. The propagation rates we found are in concordance with maximal rhizome elongation rates reported in the literature (Duarte 1991).

For soft-bottom colonizing angiosperms, very few other facilitating non-consumer plant-animal interactions have yet been studied experimentally. Bertness (1984) worked on the interaction between the cord grass Spartina alterniflora and a mytilid mussel, Geukensia demissa, in northeastern USA salt marshes. In accord with the present study, S. alterniflora benefited from the fertilization by the mussel through a higher net production and an elevated ratio of aboveground to belowground biomass.

\section{Ecological implications}

Since 1950, the Western Baltic has received increasing nutrient input from human activity (Larsson et al. 1985). As a consequence, the biomass of macrozoobenthos and especially filter-feeding molluscs has increased above the halocline due to increased food supply (Cederwall \& Elmgren 1980). The Fucus vesiculosus community of the Baltic proper has been replaced by mussels near the lower distribution limit of F. vesiculosus (Kautsky et al. 1992). In Kiel Bight, the macrozoobenthos biomass in general, and especially of blue mussels, has increased since 1960 (Brey 1986). Eutrophication may favour filter feeders, while seagrasses including Zostera marina are known to be weakened by eutrophication-induced turbidity in many parts of the world (Orth \& Moore 1983, Giesen et al. 1990, Walker \& McComb 1992). Although few hard data are available, these processes are also likely to have occurred in Kiel Fjord since this site receives even more anthropogenic nutrients than the open Kiel 
Bight due to the discharge of the Schwentine River (Stienen 1986).

Our data from Kiel Fjord indicate that the 2 processes, the decline of eelgrass and increase of mussel biomass, do not reinforce each other. Instead, an understory of mussels mitigates nutrient limitation of Zostera marina. Since the depth distribution of eelgrass has moved upwards due to light limitation (Kobarg 1993), the principal distribution range of Z. marina in Kiel Fjord becomes more and more restricted to the very shallow subtidal ( 1 to $3 \mathrm{~m}$ depth). In these depths, the sediments are often sandy and organically poor since organic matter never accumulates due to wave exposure.

Additionally, mussels may even improve the light transmittance to eelgrass by decreasing water turbidity through their filtering activity.

This study presents evidence that deterioration of Zostera marina stands by mussels does not occur in 2 shallow subtidal sites. This may change if, after a series of calm winters without major disturbances, most of the sand became covered by mussels. We hypothesize that large mussel patches which develop in this way may be able to destroy Z. marina simply by force of their combined growth extensions.

We suggest that future work should be directed to test the hypotheses whether (1) there are conditions under which an understory of mussels may harm eelgrass and (2) the co-occurrence of $Z$. marina and Mytilus edulis is a trade-off between beneficial effects for eelgrass through mussel fertilization and negative effects through interference.

Acknowledgements. We thank numerous divers of the scientific diving group at the University of Kiel for their field assistance and the crew of the vessel 'Sagitta', K. Meller and H. Schramm for their patience. The study was partly funded by the Ministry of Environment of Schleswig-Holstein (contract 'Erfassung der Flachwassergemeinschaften') and by a grant (HSP II) from the Ministry of Education to T.R. We are very grateful to the German Navy in Friedrichsort (Wehrtechnische Dienststelle 71) for allowing us access to the restricted area. A. Albrecht and A. Peters made very helpful comments to earlier drafts. We gratefully acknowledge the brilliance of $W$. Huckriede in developing the image analysis software.

\section{LITERATURE CITED}

Barko, J. W., Gunnison, D., Carpenter, S. R. (1991). Sediment interactions with submersed macrophyte growth and community dynamics. Aquat. Bot. 41: 41-65

Bernstein, I. H. (1987). Applied multivariate statistic. SpringerVerlag, New York

Bertness, M. D. (1984). Ribbed mussels and Spartina alterniflora production in a New England salt marsh. Ecology 65: $1794-1807$
Bertness, M. D., Grossholz, E. (1985). Population dynamics of the ribbed mussel, Geukensia demissa: the costs and benefits of an aggregated distribution. Oecologia 67 : $192-204$

Brenchley, G. A. (1982). Mechanisms of spatial competitıon in marine soft-bottom communities. J. exp. mar. Biol. Ecol. 60: $17-33$

Brey, $T$ (1986). Increase in macrozoobenthos above the halocline in Kiel Bay comparing the 1960s with the 1980s. Mar. Ecol. Prog. Ser 28: 299-302

Cederwall, H., Elmgren, R. (1980). Biomass increase of benthic macrofauna demonstrates eutrophication of the Baltic Sea. Ophelia Suppl 1: 287-304

Dayton, P. K. (1971). Competition, disturbance, and community organization: the provision and subsequent utilization of space in a rocky intertidal community. Ecol. Monogr. 41: $351-389$

Dennison, W. C., Aller, R. C., Alberte, R. S. (1987). Sediment ammonium availability and eelgrass (Zostera marina) growth. Mar. Biol. 94: 469-477

Dijkema, R., Bol, J., Vroonland, C. S. (1987). Enhancement of the production of cockles (Cerastoderma edule L.) by thinning out a dense natural bed and reseeding, Oosterschelde, SW Netherlands. Comm. Meet. int. Coun. Explor. Sea C.M.-ICES 87/K: 12

Duarte, C. M. (1991). Allometric scaling of seagrass form and productivity. Mar. Ecol. Prog. Ser. 77: 289-300

Fahrmeir, L., Hamerle, A. (1984). Multivariate statistische Verfahren. Walter de Gruyter, Berlin

Farrell, T M. (1989). Succession in a rocky intertidal community: the importance of disturbance size and position within a disturbed patch. J. exp. mar. Biol. Ecol. 128: $57-73$

Fréchette, M., Lafaivre, D. (1990). Discriminating between food and space limitation in benthic suspension feeders using self-thinning relationships. Mar. Ecol. Prog. Ser. 65: $15-23$

Giesen, W. B. J. T., van Katwijk, M. M., den Hartog, C. (1990). Eelgrass condition and turbidity in the Dutch Wadden Sea. Aquat. Bot. 37: 71-85

Grasshoff, K. (1976). Determination of nitrate. In: Grasshoff, K. (ed.) Methods of seawater analysis. Verlag Chemie, Weinheim, p. 137-145

Gründel, E. R. (1980). Ökosystem Seegraswiese: qualitative und quantitative Untersuchungen über Struktur und Funktion einer Zostera-Wiese vor Surendorf (Kieler Bucht, Westliche Ostsee). Dissertation, University of Kiel

Hamburg, S. P., Homann, P. S. (1986). Utilization of growth parameters of eelgrass, Zostera marina, for productivity estimation under laboratory and in situ conditions. Mar. Biol. 93: 299-303

Harger, J. R. W. (1972). Competitive coexistence: maintenance of interacting associations of the sea mussels Mytilus edulis and Mytilus californianus. Veliger 14:387-410

Hawkins, D. M. (1981). A new test for multivariate normality and homoscedasticity. Technometrics 23: 105-110

Howell, D. C. (1992). Statistical methods for psychology, 3rd edn. Duxbury Press, Belmont, CA

Hurlbert, S. H. (1984). Pseudoreplication and the design of field experiments. Ecol. Monogr. 54: 187-211

Janke, K. (1990). Biological interactions and their role in community structure in the rocky intertidal of Helgoland (German Bight, North Sea). Helgoländer Meeresunters. 44: $219-263$

Johnson, C. R., Field, C. A. (1993). Using fixed-effects model multivariate analysis of variance in marine biology and ecology. Oceanogr. mar. Biol. A. Rev. 31-177-221 
Kautsky, H., Kautsky, L., Kautsky, N., Kautsky, U., Lindblad, C. (1992). Studies on the Fucus vesiculosus community in the Baltic Sea. Acta Phytogeogr. Suec. 78: 33-48

Kautsky, N., Evans, S. (1987). Role of biodeposition by Mytilus edulis in the circulation of matter and nutrients in a Baltic coastal ecosystem. Mar. Biol, Prog. Ser. 38: 201-212

Kautsky, N., Wallentinus, I. (1980). Nutrient release from a Baltic Mytilus-red algal community and its role in benthic and pelagic productivity. Ophelia Suppl. 1: 17-30

Kenworthy, W. J., Fonseca, M. (1977). Reciprocal transplant of the seagrass Zostera marina L. Effect of substratum on growth. Aquaculture 12: 197-213

Kobarg, N. (1993). Faktoren, die die Verbreitung von Zostera marina kontrollieren. Diplomarbeit, University of Kiel

Koroleff, F. (1976a). Determination of ammonium. In: Grasshoff, K. (ed.) Methods of seawater analysis. Verlag Chemie, Weinheim, p. 126-132

Koroleff, F. (1976b). Determination of phosphorus. In: Grasshoff, K. (ed.) Methods of seawater analysis. Verlag Chemie, Weinheim, p. 117-126

Larsson, U., Elmgren, R., Wulff, F. (1985). Eutrophication of the Baltic Sea - causes and consequences. Ambio 14: $9-14$

Lütkepohl, H. (1991). Multivariate Verfahren I. Institut für Statistik und Ökonometrie. University of Kiel

McCook, L. J., Chapman, A. R. O. (1991). Community succession following massive ice-scour on an exposed rocky shore: effects of Fucus canopy algae and of mussels during late succession. J. exp. mar. Biol. Ecol. 154: 137-169

Menge, B. A. (1976). Organization of the New England rocky intertidal community: role of predation, competition, and environmental heterogeneity. Ecol. Monogr. 46: 355-393

Murray, L., Dennison, W. C., Kempf, W. M. (1992). Nitrogen versus phosphorus limitation for growth of an estuarine population of eelgrass (Zostera marina L.). Aquat. Bot. 44: $83-100$

Orth, R. J. (1977). Effect of nutrient enrichment on growth of the eelgrass Zostera marina in the Chesapeake Bay, Virginia, USA. Mar. Biol. 44: 187-194

Orth, R. J., Moore, K. A. (1983). Chesapeake Bay: an unprecedent decline in submerged aquatic vegetation. Science 222: $51-53$

Paine, R. T. (1971). A short-term experimental investigation of resource partitioning in a New Zealand rocky intertidal habitat. Ecology 52: 1096-1106

Paine, R. T (1974). Intertidal community structure: experimental studies on the relationship between a dominant competitor and its principal predator. Oecologia 15: $93-120$

Pedersen, M. F., Borum, J. (1993). An annual nitrogen budget

This article was presented by R. N. Hughes (Senior Editorial Advisor), Bangor, Gwynedd, UK for a seagrass Zostera marina population. Mar. Ecol. Prog Ser. 101: 169-177

Peterson, C. H. (1977). Competitive organization of the softbottom macrobenthic communities of southern California lagoons. Mar. Biol. 43: 343-359

Peterson, C. H. (1979). Predation, competitive exciusion, and diversity in the soft-sediment benthic communities of estuaries and lagoons. In: Livingston, R. J. (ed.) Ecological processes in coastal and marine systems. Plenum Press, New York, p. 233-264

Philip, G. (1936). An enalid plant association in the Humber estuary. J. Ecol. 26: 205-219

Ruth, M. (1991). Miesmuschelfischerei im schleswigholsteinischen Wattenmeer. Ein Beispiel für die Problematik einer Fischerei im Nationalpark. In: Dethlefsen, V. (ed.) Probleme der Muschelfischerei im Wattenmeer. Schriftenreihe der Schutzgemeinschaft Deutsche Nordseeküste e. V., Bremerhaven, p. 26-46

Sand-Jensen, K. (1975). Biomass, net production and growth in an eelgrass (Zostera marina L.) population in Vellerup Vig, Denmark. Ophelia 14: 185-210

Schwenke, H. (1969). Meeresbotanische Untersuchungen in der westlichen Ostsee als Beitrag zu einer marinen Vegetationskunde. Int. Rev. ges. Hydrobiol. 54: 35-94

Short, F. T (1983a). The response of interstitial ammonium in eelgrass (Zostera marina L.) beds to environmental perturbations. J. exp. mar. Biol. Ecol. 68: 195-208

Short, F. T (1983b). The seagrass, Zostera marina L.: plant morphology and bed structure in relation to sediment ammonium in Izembek Lagoon, Alaska. Aquat. Bot. 16 $149-161$

Short, F. T (1987). Effects of sediment nutrients on seagrass: literature review and mesocosm experiments. Aquat. Bot. 27: $41-57$

Short, F. T., McRoy, C. P. (1984). Nitrogen uptake by leaves and roots of the seagrass Zostera marina L. Botanica mar. 27: $547-555$

Stienen, C. (1986). Increased nutrient load and phytoplankton bloom in Kiel Fjord as compared with Kiel Bight, Western Baltic. Ophelia Suppl. 4: 259-271

Walker, D. I., McComb, A. J. (1992). Seagrass degradation in Australian coastal waters. Mar. Pollut. Bull. 25: 191-195

Williams, S. L. (1990). Experimental studies of Carribean seagrass bed development. Ecol. Monogr. 60: 449-469

Williams, S. L., Ruckelshaus, M. H. (1993). Effects of nitrogen availability and herbivory on eelgrass (Zostera marina) and epiphytes. Ecology 74: 904-918

Woodin, S. A (1976). Adult-larval interactions in dense infaunal assemblages: patterns of abundance. J. mar. Res. $34: 25-41$

Manuscript first received: November 30, 1993

Revised version accepted: February 8, 1994 